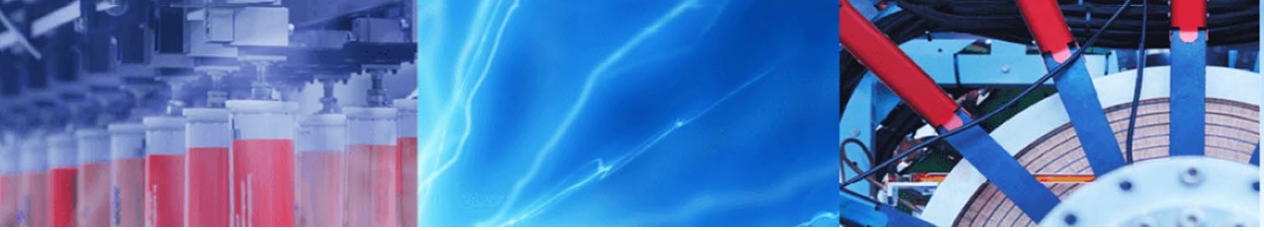

Research Article

\title{
Geomechanical characterization of a heterogenous rock mass using geological and laboratory test results: a case study of the Niobec Mine, Quebec (Canada)
}

\author{
Shahriyar Heidarzadeh ${ }^{1}$ (D) Ali Saeidi ${ }^{1}$. Catherine Lavoie ${ }^{1}$. Alain Rouleau ${ }^{1}$
}

Received: 25 September 2020 / Accepted: 29 April 2021

Published online: 17 May 2021

(c) The Author(s) $2021 \quad$ OPEN

\begin{abstract}
To conduct a successful geomechanical characterization of rock masses, an appropriate interpretation of lithological heterogeneity should be attained by considering both the geological and geomechanical data. In order to clarify the reliability and applicability of geological surveys for rock mechanics purposes, a geomechanical characterization study is conducted on the heterogeneous rock mass of Niobec Mine (Quebec, Canada), by considering the characteristics of its various identified lithological units. The results of previous field and laboratory test campaigns were used to quantify the variability associated to intact rock geomechanical parameters for the different present lithological units. The interpretation of geomechanical similarities between the lithological units resulted in determination of three main rock units (carbonatite, syenite, and carbonatite-syenite units). Geomechanical parameters of these rock units and their associated variabilities are utilized for stochastic estimation of geomechanical parameters of the heterogeneous rock mass using the Monte Carlo Simulation method. A comparison is also made between the results of probabilistic and deterministic analyses to highlight the presence of intrinsic variability associated with the heterogeneous rock mass properties. The results indicated that, for the case of Niobec Mine, the carbonatite-syenite rock unit could be considered as a valid representative of the entire rock mass geology since it offers an appropriate geomechanical approximation of all the present lithological units at the mine site, in terms of both the magnitude and dispersion of the strength and deformability parameters.
\end{abstract}

\section{Article Highlights}

- Evaluating the reliability and applicability of geological survey outcomes for rock mechanics purposes.

- A geomechanical characterization study is conducted on the heterogeneous rock mass by considering the various identified rock lithotypes.

- The geomechanical parameters of intact units and their associated variabilities are used to stochastically estimate the geomechanical parameters of the heterogeneous rock mass by employing the Monte Carlo Simulation.

- A comparison is also made between the results of probabilistic and deterministic geomechanical analyses.

- The results indicate that, in the case of Niobec Mine, the combined syenite-carbonatite rock unit could be considered as a valid representative of the entire rock mass.

Keywords Rock mass characterization · Intact rock parameters - Lithological heterogeneity · Inherent variability . Laboratory tests $\cdot$ Niobec mine

Shahriyar Heidarzadeh, shahriyar.heidarzadeh1@uqac.ca | 'Department of Applied Sciences, Université du Québec à Chicoutimi, Chicoutimi, QC G7H 2B1, Canada.

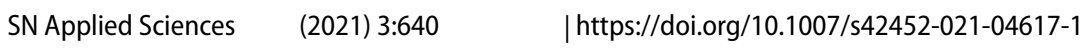




\section{Introduction}

Site characterization is an essential preliminary phase for implementing a successful rock mechanics program in any underground mining activity. As part of an underground mining plan, site characterization facilitates the subsequent geomechanical classifications by determining the geological settings and lithological characteristics of the area in which the mining activity is taking place. Aside from determining the geological settings and/or hydrogeological characteristics of the mining environment, site characterization contributes in estimation of the strength and deformability parameters of the numerous lithological units identified within the rock mass at the mine site [1,2]. In fact, prior to any geomechanical investigation on rock mass, it is essential to characterize the intact rock in terms of lithological variability, by considering the mechanical properties of the key constituent lithological units [3-5].

From a geological perspective, various intact lithological units can be distinguished based on their lithological and petrographic differences. In some cases, numerous units could be identified within the rock having slight differences in mineral assemblage or alteration intensity $[5,6]$. This approach of dealing with numerous identified lithological units may not be desirable in a geomechanical perspective since it could impose unnecessary complexities in rock mass classification/characterizations or numerical stability analysis. On the other hand, assuming only strong or only weak intact rock quality would either be too conservative or result in overestimation of rock mass strength $[5,7]$. Therefore, a typical solution to deal with lithological heterogeneity of rock in a geomechanical perspective, could be through defining a periodic presence of strong and weak rock units with their corresponding geomechanical properties.

Lithological heterogeneity should be considered when estimating the geomechanical parameters of rock masses. Variable lithological compositions along with the presence of geological structures would result in anisotropy and heterogeneity in rock mass properties. Heterogeneity and anisotropy in rock mass geomechanical characteristics, originate from the presence of multiple rock formations having horizons with different alternations $[2,5]$. The existing uncertainty in the strength and deformability parameters of a rock mass stems from the inherent variability associated with the rock formation process as well as a general lack of knowledge throughout the characterization process. The inevitable presence of such uncertainties in intact rock properties, complicates the process of rock mass characterization for a reliable estimate of rock mass properties $[6,8]$.

Different methods for estimating the strength and deformability parameters have been used in geomechanical characterization of rock masses. However, employment of the empirical Hoek-Brown failure criterion in conjunction with the Geological Strength Index (GSI) classification system has been reported to be the most common method for estimation of rock mass properties [9-11]. Conventional deterministic application of the above-mentioned approach, is not capable of addressing the intrinsic variable nature of rock masses since the inherent variability of the parameters are not taken into account. Probabilistic estimation of rock mass properties on the other hand, would be capable of incorporating the inherent variability of geomechanical parameters and depict a more realistic picture of the rock mass geomechanical behavior [6, 11-15].

The application of probabilistic methods in rock mass geomechanical characterization have been studied in many researches at different domains of geotechnical engineering such as rock slope stability e.g. [16-19] and underground rock mechanics such as tunnel stability [20-23], stope stability [24-26] and pillar stability [27-29]. However, few studies used probabilistic approaches to quantify the impact of lithological heterogeneity identified by geological surveys and laboratory tests on the uncertainties of the rock mass geomechanical characterization. As one of the pioneering studies, Kim and Gao [30] utilized the Monte Carlo Simulation (MCS) method to estimate the geomechanical parameters of a heterogeneous rock mass and demonstrated that the best-fitted statistical distribution for the mechanical properties of a basalt would be the third type asymptotic distribution of the smallest values. Hoek et al. [31] focused on characterization and determination of engineering properties of tectonically undisturbed sedimentary rock deposits (such as molassic formations) and recommended the use of empirical charts to estimate the GSI and $m_{i}$ values of heterogeneous rock masses. Sari et al. [6], employed the MCS method, to incorporate the uncertainties associated with the intact rock strength and discontinuity parameters into a spread sheet model using statistical distributions, to quantify the variability of rock mass properties for Ankara andesite (Turkey). Tziallas et al. [4] determined the mechanical properties of heterogeneous rocks in the laboratory and proposed a methodology for predicting the rock mass strength of flysch formations consisting of siltstone-sandstone alternations in different proportions. Pepe et al. [5], used GSI classification system in conjunction with the Hoek-Brown failure criterion for geomechanical characterization of the highly heterogeneous Sanremo flysch formation located in Western Italy. Grenon et al. [32] evaluated two successive field and laboratory campaigns to investigate intact rock properties of an underground mining project in the Canadian arctic. The obtained results were compared to the pre-defined target levels of confidence associated 
with different stages of a mining project. More recently, Contreras et al. [33] applied the Bayesian methodology to estimate the intact rock strength parameters of the Hoek-Brown failure criterion, through the analysis of data from compression and tension tests; they explained the essential differences between frequentist and Bayesian statistics in quantifying the inevitable uncertainty in experimentally determined rock mechanics parameters.

Beside the accomplished researches, further studies are yet required to clarify how lithological and petrographic heterogeneities of a rock mass should be interpreted to provide a useful input for the geomechanical characterization. Identification of numerous lithological units within a rock mass (as the output of geological site characterizations) will not necessarily provide reliable data for rock mechanics experts since the geomechanical parameters of the identified lithological units may not show considerable differences. In fact, the best practice to deal with numerous identified lithological units within rocks should be developed and characterized for rock mechanics experts, not only to increase the efficiency but also to decrease the confusion caused by the presence of dozens of different lithological units, in geomechanical characterization process of heterogeneous rock masses.

To this end, this study uses the results of geological surveys to conduct a geomechanical characterization of rock, in order to evaluate the reliability and applicability of geological survey results for rock mechanics and rock engineering purposes. Geomechanical characterization is conducted on the intact rock specimens collected from the Niobec Mine (Quebec, Canada). Lithological and geomechanical properties of each identified lithological units at the mine, would be brought together from the results of previously conducted field and laboratory test campaigns. lithological similarities between the various constituent lithological units along with the expert judgment would be considered to identify main representative rock units at the Niobec Mine. Subsequently, the geomechanical parameters of each rock unit would be determined and their associated variabilities would be quantified and used to estimate the geomechanical parameters of the entire heterogeneous rock mass. For this purpose, MCS method will be employed to provide a stochastic estimation of strength and deformability parameters of rock mass using Hoek-Brown failure criterion in conjunction with GSI classification method. A comparison will also be made between the results of probabilistic and deterministic analyses to highlight the presence of intrinsic variabilities associated to the heterogeneous rock mass properties. Finally, a valid representative rock unit will be chosen over the others providing the most reasonable and reliable approximation of the geomechanical characteristics for the entire rock mass at the Niobec Mine.

\section{Niobec Mine}

The Niobec underground mine as part of the Saint-Honoré alkaline complex is located $13 \mathrm{~km}$ northwest of the city of Saguenay (Chicoutimi) within the limits of the municipality of Saint-Honoré, Quebec, Canada (Fig. 1).

The local geology of the region consists of an elliptical-shaped late Precambrian/early Cambrian intrusion core of alkaline silicates (syenite) and dolomitic/calcitic carbonatites [34]. The intrusion is overlain by an average of $75 \mathrm{~m}$ of Paleozoic limestone and dolomite of Trenton group [35]. Carbonatite in the intrusion core may have a fine to coarse grain dolomitic or calcitic composition. Carbonatite is brecciated or foliated in texture and contains variable amounts of accessory minerals (such as biotite, magnetite, apatite, pyrite, chlorite and pyrochlore). The foliation is often defined by the alignment of accessory minerals which are constituted from 1 to $10 \%$ of the total mineral assemblage [34]. The brecciated carbonatite contains $15 \%$ to $90 \%$ of syenite fragments from a few centimeters to approximately $10 \mathrm{~m}$ in size, showing total or partial alteration to chlorite. Furthermore, the hematitic alteration of carbonatite is also observed with variable intensities. The intrusion core is surrounded by massive or brecciated syenite having different degrees of alteration to chlorite [35]. The zones of economic mineralization in the deposit correspond to irregular shaped sub-vertical lenses oriented towards east-west direction with variable thickness of 73-171 m [34].

\subsection{Geological description of the rock mass}

As mentioned above, the core of the intrusion at the SaintHonore alkaline complex is formed by syenite and carbonatite and the whole deposit is surrounded by syenite [34]. By means of the thin section analysis and macroscopic images, the identified lithological units at the Niobec Mine were grouped into three main rock units based on their mineral compositions and content of syenite fragments namely carbonatite, syenite and brecciated carbonatitesyenite. Carbonatite which is competent in term of quality, can contain various accessory minerals such as magnetite, biotite, apatite, chlorite and pyrite whose concentrations vary from 1 to $10 \%$. These minerals are often present as foliation in carbonatite without affecting the resistance of the unit. Carbonatite can be massive to brecciated and can be altered to hematite in different degrees. Carbonatite is brecciated when it contains from 15 to $90 \%$ of syenite fragments. Partial or total alteration to chlorite can occur, resulting in resistance reduction in the brecciated carbonatite. The resistance of syenite varies depending on its degree of alteration $[34,35]$. 


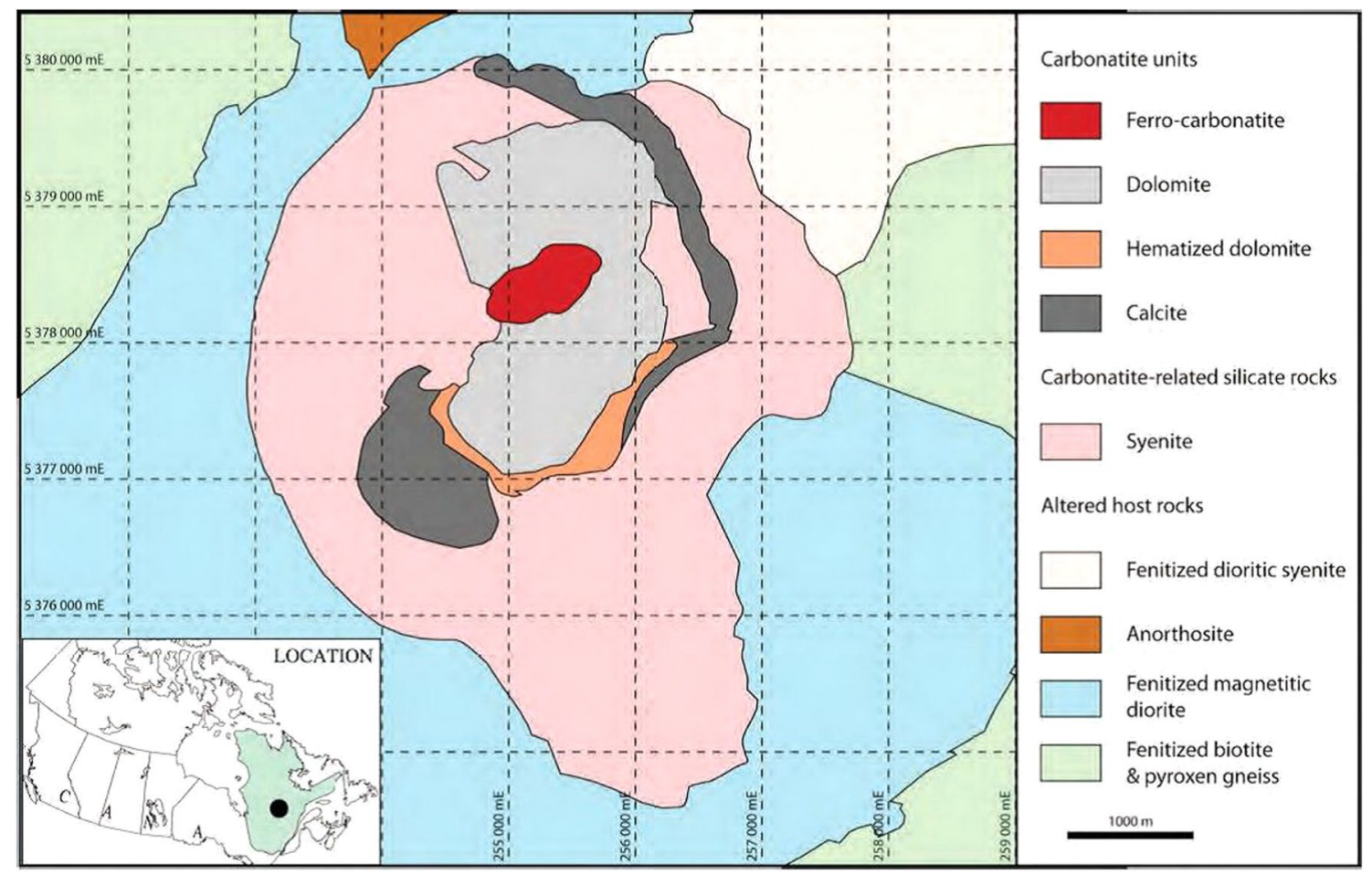

Fig. 1 Geological map of the Saint-Honoré alkaline complex (after Tremblay et al. 2017)

A lithological classification system has been developed based on the rock's composition, grain size and level of accessory minerals to standardize the information regarding the geological description of drill core samples [37]. The various rocks forming the alkaline complex are codified according to their main mineral compositions and categorized into different lithological units. Accordingly, the first category was distinguished by dominance of carbonatite in its composition, while the second category was distinguished by the dominance of syenite. Furthermore, the third category included lithologies associated with particular cases or any other lithological units excluded from the first two categories. The codes which were used to designate the different lithological units, start with the letter "S" if the rock contains between 50 and $95 \%$ of syenite fragments and with the letter " $C$ " if contains less than $5 \%$ of syenite fragments. Moreover, if the rock contains between 5 and $49 \%$ of syenite in its composition, the suffix "S" was added to the type of carbonatite. The rock was designated by the code "Si" or "Sa" if it contains more than $95 \%$ of syenite and respectively when not altered and altered in chlorite. Table 1 presents the geological codes established and used by the Niobec Mine authorities to describe the different lithological units identified within the rock mass. A detailed description of the codes attributed to each lithological unit utilized in Table 1 , is provided by Lajoie [35].

\section{The geomechanical parameters of the intact rock}

Over the past years, various mapping and drilling campaigns have conducted laboratory tests on core samples extracted from different locations within the rock mass at the Niobec Mine [35, 38-44] to determine the physical and mechanical properties of various existing intact rock units. Table 2 presents the type and number of laboratory tests conducted by different campaigns at the Niobec Mine. Detailed information on the methodologies and specifications of each measuring campaign is provided by Lajoie [35].

The laboratory test results for all the campaigns were compiled and gathered into a database to facilitate the analysis of data. The generated dataset was also revised by Itasca [45] as part of a feasibility study conducted on the mine operation to assess the possibility of applying block caving method. The results were firstly grouped based on similarities of the identified lithological units and secondly based on the depth at which the samples were taken. The analysis of the results indicated that the variation of geomechanical properties, is mainly caused by the lithological differences rather than the depth. In fact, review of the laboratory test results demonstrated that the intact geomechanical properties show large variations in the average values calculated for different 
Table 1 The codified classification established and used by the Niobec Mine to describe the different lithological units. Adapted from Golder [34] and Lavoie [37]
Table 2 The type and number of laboratory tests conducted by different campaigns at the Niobec Mine

\begin{tabular}{llllllllll}
\hline 1 & C1 & 13 & C3CS & 25 & C3W & 37 & SC2 & 49 & SCCA \\
\hline 2 & C2 & 14 & C3D & 26 & C5 & 38 & SC3A & 50 & BR \\
3 & C2C & 15 & C3DS & 27 & C5bio & 39 & SC3B & 51 & Bt \\
4 & C2CS & 16 & C3N & 28 & C5S & 40 & SC3C & 52 & Cal \\
5 & C2S & 17 & C3NA & 29 & C6 & 41 & SC3N & 53 & LAMP \\
6 & C2sucre & 18 & C3NAS & 30 & C6S & 42 & SC3NA & 54 & SM \\
7 & C3A & 19 & C3NB & 31 & C9 & 43 & SC3NB & 55 & Null \\
8 & C3AS & 20 & C3NBS & 32 & C9S & 44 & SC3NC & & \\
9 & C3B & 21 & C3NS & 33 & CCA & 45 & SC3NT & & \\
10 & C3BS & 22 & C3NT & 34 & CCAS & 46 & SC5 & & \\
11 & C3Bt & 23 & C3NTC & 35 & Si & 47 & SC5bio & & \\
12 & C3C & 24 & C3NTS & 36 & Sa & 48 & SC9 & &
\end{tabular}

C3C: Calcitic carbonatite containing a few accessory minerals

C3N: Fine-grained dolomitic carbonatite containing a few accessory minerals. Colored as Dark wine red. Partially altered in hematite

C3NA: Fine-grained dolomitic carbonatite containing variable concentrations of biotite and apatite. Normally foliated. Contains below $5 \%$ of magnetite

C3NB: Fine-grained dolomitic carbonatite containing variable concentrations of biotite and apatite. Normally foliated. Contains over $5 \%$ of magnetite

C5: Medium to coarse-grained dolomitic carbonatite with no accessory minerals

C5bio: Medium to coarse-grained dolomitic carbonatite with over $10 \%$ biotite

C3A: Medium-grained dolomitic carbonatite with variable concentrations of biotite and apatite. Typically foliated with magnetite concentrations below $5 \%$

C3B: Medium-grained dolomitic carbonatite with variable concentrations of biotite and apatite. Typically foliated with magnetite concentrations over $5 \%$

Sy: Unaltered syenite

Sa: Syenite altered in chlorite between 10 and $100 \%$. In the case of $100 \%$ alteration, the code $\mathrm{CH}$ is attributed

First category with the carbonatite dominance (from 1 to 34), second category with the syenite dominance (from 35 to 49 ) and the third category containing all the remaining lithological units (from 50 to 55)

\begin{tabular}{lccccl}
\hline Test campaigns, (year) & \multicolumn{5}{l}{ Type and number of conducted laboratory tests } \\
\cline { 2 - 6 } & Brazilian test & $\begin{array}{l}\text { Three-point } \\
\text { bending test }\end{array}$ & $\begin{array}{l}\text { Uniaxial } \\
\text { compression } \\
\text { test }\end{array}$ & $\begin{array}{l}\text { Triaxial } \\
\text { compression } \\
\text { test }\end{array}$ & $\begin{array}{l}\text { Test for elastic } \\
\text { moduli of intact } \\
\text { rock }\end{array}$ \\
\hline Bétournay, 1986 & 22 & 10 & 24 & & 34 \\
Labrie 1987 & 155 & & 79 & 14 & 12 \\
Labrie 1997 & 25 & & 6 & 12 & 18 \\
Desbiens 1997 & 16 & 16 & 35 & 31 & 17 \\
Corthésy 2000 & 17 & & 17 & 6 & \\
Labrie and Conlon 2005 & & & 5 & & 5 \\
Lajoie 2010 & 9 & 11 & 26 & 19 & 5 \\
Grenon 2013 & 43 & & 43 & & \\
Total & 287 & 37 & 235 & 82 & 91
\end{tabular}

lithological units within the same test campaign (Tables 3 and 4). Considering the intrinsic nature of the rock materials, there is an uncertainty associated with each of the intact rock parameters, especially when compared to manmade materials. This uncertainty is generated through the process of formation and continuous modification of rock over its geologic history and results in both micro and macro scale property variations from one spatial location to another [8]. The variability associated with the intact 
rock's strength and deformability parameters are presented in Figs. 2 and 3.

Inherent variability in uniaxial compressive strength $\left(\sigma_{c}\right)$ and tensile strength $\left(\sigma_{t}\right)$ stems from the variability of index properties and petrographic characteristics of rock. According to Langford and Diederichs [8], index properties (e.g., the total porosity, density, water content and durability) should be consistent for the rock specimens taken from the same formation (lithological context). While, variations in petrographic characteristics develop different patterns of micro cracks within each rock sample, resulting in variability of uniaxial compressive and tensile strength values. Variability in petrographic characteristics is defined by the variation in grain size and shape, texture (degree of interlocking), micro fractures (grain boundaries, mineral cleavages), nature of cement, degree of chemical alteration and anisotropy (orientation of the cracks and the condition of stress distribution). Similarly, variability in the deformability parameters such as Young's Modulus and the Poisson's ratio is generated due to the variation in parameters such as porosity and degree of jointing, water content and the vibration effects from blasting [8].

In order to quantify the existing variability associated to the intact strength and deformability parameters at the Niobec Mine, lithological units were examined in different categories. Firstly, the strength and deformability parameters of the carbonatite units containing few accessory minerals $(\mathrm{C} 5, \mathrm{C} 3 \mathrm{~N}$ and $\mathrm{CCA})$ were compared with those of the foliated units and containing many accessory minerals (C3C, C3A, C3NA, C3B and C3D). Secondly, the strength and deformability parameters of calcific units (C3C, C3D and CCA), were compared to those of dolomitic (C3A, C3B, C5, C3N and C3NA) and syenitic units. Finally, third comparison was made between the strengths and deformability parameters of northern units (C3N, C3NA and (3NT) and all other units [37]. The average values of Young's modulus and Poisson's ratio as well as the uniaxial compressive and tensile strength for each lithological unit obtained from the previous test campaigns are presented respectively in Tables 3 and 4.

Studying the obtained results specified that the largest variations belong to the carbonatitic lithological units. These variations in strength and deformability parameters showed a significant dependence on the degree of alteration.

Box-plot diagrams (Figs. 4 and 5) illustrate the dispersion of strength and deformability test results. Box-plot diagrams are able to compare the series of obtained results for the main lithological units and identify the outliers to be excluded for further calculations. It was indicated that the syenite has lower quality than carbonatite in terms of geomechanical properties. The average values of strength and deformability parameters of carbonatite and
Table 3 The average values of Young's modulus and Poisson's ratio for each lithological unit

\begin{tabular}{|c|c|c|c|c|c|c|}
\hline Test campaign, (year) & $E_{\text {Ave. }}[\mathrm{GPa}]$ & s.d [GPa] & $\begin{array}{l}\text { Number } \\
\text { of tests }\end{array}$ & $v_{\text {Ave. }}[\mathrm{MPa}]$ & s.d & $\begin{array}{l}\text { Num- } \\
\text { ber of } \\
\text { tests }\end{array}$ \\
\hline \multicolumn{7}{|l|}{ Labrie (1987) } \\
\hline C5 & 77.40 & 2.23 & 4 & 0.30 & 0.04 & 4 \\
\hline C3A & 55.75 & 18.60 & 2 & 0.26 & 0.02 & 2 \\
\hline $\mathrm{C} 3 \mathrm{C}$ & 58.15 & 5.16 & 2 & 0.31 & 0.06 & 2 \\
\hline $\mathrm{C} 3 \mathrm{~N}$ & 64.40 & - & 1 & 0.26 & - & 1 \\
\hline Sy & 37.00 & 0.57 & 2 & 0.26 & 0.05 & 3 \\
\hline \multicolumn{7}{|l|}{ Labrie (1997) } \\
\hline C5 & 64.85 & 7.39 & 6 & 0.24 & 0.09 & 6 \\
\hline $\mathrm{C} 3 \mathrm{~N}$ & 74.38 & 10.65 & 6 & 0.23 & 0.08 & 6 \\
\hline Sy intact & 53.39 & 4.52 & 3 & 0.25 & 0.12 & 3 \\
\hline Sy altered & 51.25 & 7.28 & 3 & 0.19 & 0.08 & 3 \\
\hline \multicolumn{7}{|l|}{ Desbiens (1997) } \\
\hline C5 & 76.15 & 18.42 & 2 & 0.31 & 0.06 & 2 \\
\hline C5bio & 90.25 & - & 1 & 0.29 & - & 1 \\
\hline $\mathrm{C} 3 \mathrm{~A}$ & 59.66 & 5.64 & 3 & 0.19 & 0.08 & 3 \\
\hline $\mathrm{C} 3 \mathrm{~N}$ & 84.95 & 5.74 & 3 & 0.32 & 0.01 & 3 \\
\hline C3NB & 64.28 & 3.52 & 3 & 0.23 & 0.05 & 3 \\
\hline Sy altered & 47.21 & 4.68 & 3 & 0.24 & 0.06 & 3 \\
\hline \multicolumn{7}{|c|}{ Labrie and Conlon (2005) } \\
\hline C3B & 36.66 & 0.51 & 3 & 0.34 & 0.00 & 2 \\
\hline
\end{tabular}

${ }^{*}$ s.d standard deviation 
Table 4 The average uniaxial compressive and tensile strength values for each lithological unit

\begin{tabular}{|c|c|c|c|c|c|c|}
\hline $\begin{array}{l}\text { Test campaigns, } \\
\text { (year) }\end{array}$ & $\sigma_{c \text { Ave. }}[\mathrm{MPa}]$ & s.d [MPa] & Number of tests & $\sigma_{t \text { Ave. }}[\mathrm{MPa}]$ & s.d [MPa] & Number of tests \\
\hline \multicolumn{7}{|l|}{ Labrie (1987) } \\
\hline $\mathrm{C} 5$ & 120.15 & 35.81 & 40 & 9.64 & 1.71 & 68 \\
\hline C3A & 93.93 & 29.68 & 5 & 7.25 & 1.39 & 19 \\
\hline $\mathrm{C} 3 \mathrm{C}$ & 85.58 & 21.81 & 7 & 8.99 & 1.35 & 18 \\
\hline $\mathrm{C} 3 \mathrm{~N}$ & 109.25 & 23.30 & 9 & 8.46 & 2.06 & 13 \\
\hline Sy intact & 99.06 & 16.94 & 7 & 8.23 & 1.21 & 15 \\
\hline Sy altered & 68.70 & 16.48 & 4 & 5.72 & 1.29 & 11 \\
\hline \multicolumn{7}{|l|}{ Labrie (1997) } \\
\hline C5 & 107.19 & 35.23 & 2 & 7.04 & 2.02 & 9 \\
\hline $\mathrm{C} 3 \mathrm{~N}$ & 147.99 & 68.04 & 2 & 10.25 & 1.42 & 7 \\
\hline Sy intact & 139.71 & - & 1 & 8.97 & 0.64 & 5 \\
\hline Sy altered & 85.75 & - & 1 & 8.96 & 1.63 & 4 \\
\hline \multicolumn{7}{|l|}{ Desbiens (1997) } \\
\hline C5 & 126.47 & 32.31 & 6 & 8.66 & 1.48 & 2 \\
\hline $\mathrm{C} 5 \mathrm{~S}$ & 121.89 & - & 1 & - & - & - \\
\hline $\mathrm{C} 3 \mathrm{~A}$ & 106.15 & 72.41 & 2 & - & - & - \\
\hline C3B & 117.89 & 13.69 & 4 & 7.76 & 1.69 & 2 \\
\hline $\mathrm{C} 3 \mathrm{~N}$ & 118.19 & 38.10 & 5 & 6.07 & 1.19 & 3 \\
\hline C3NA & 115.89 & 56.24 & 3 & 12.94 & - & 1 \\
\hline C3NB & 163.10 & 29.37 & 3 & 7.97 & 1.35 & 2 \\
\hline Sy intact & 87.92 & 10.63 & 4 & 5.69 & 1.28 & 2 \\
\hline Sy altered & 83.30 & 28.93 & 6 & 6.50 & 1.70 & 3 \\
\hline \multicolumn{7}{|l|}{ Corthésy (2000) } \\
\hline C5S & 111.94 & 36.02 & 5 & 7.01 & 1.16 & 5 \\
\hline $\mathrm{C} 3 \mathrm{C}$ & 94.61 & 13.95 & 5 & 9.25 & 0.42 & 4 \\
\hline Sy & - & - & - & 9.16 & 0.70 & 2 \\
\hline \multicolumn{7}{|c|}{ Labrie and Conlon (2005) } \\
\hline $\mathrm{C} 3 \mathrm{~B}$ & 66.45 & 13.85 & 5 & - & - & - \\
\hline \multicolumn{7}{|l|}{ Lajoie (2010) } \\
\hline C5 & 116.21 & 27.78 & 2 & - & - & - \\
\hline C5bio & 97.74 & 6.86 & 3 & - & - & - \\
\hline $\mathrm{C} 3 \mathrm{~A}$ & 89.03 & 36.08 & 9 & 8.59 & 1.72 & 5 \\
\hline C3AS & 67.38 & 35.23 & 3 & - & - & - \\
\hline C3B & 104.91 & 30.47 & 7 & 7.14 & 1.05 & 4 \\
\hline SC5 & 109.30 & - & 1 & - & - & - \\
\hline \multicolumn{7}{|l|}{ Grenon (2013) } \\
\hline $\mathrm{C} 5$ & 141.63 & - & 1 & 11.22 & 3.73 & 2 \\
\hline C3A & 134.94 & 31.13 & 11 & 11.06 & 1.10 & 11 \\
\hline $\mathrm{C} 3 \mathrm{~B}$ & 134.27 & 20.98 & 6 & 10.22 & 2.83 & 8 \\
\hline C3C & 108.12 & 29.18 & 5 & 9.25 & 1.65 & 6 \\
\hline $\mathrm{C} 3 \mathrm{~A} / \mathrm{C} 3 \mathrm{~B}$ & 168.04 & 12.03 & 2 & 13.20 & 0.09 & 2 \\
\hline $\mathrm{SC} 3 \mathrm{C}$ & 114.17 & - & 1 & - & - & - \\
\hline
\end{tabular}

${ }^{*}$ s.d standard deviation

syenite rock units were estimated by compiling all the data for carbonatitic and syenitic lithological units as presented in Tables 5 and 6 respectively. The number of tests considered in the calculations of the average values of strength and deformability parameters are shown in each table. 
$\sigma_{c}[\mathrm{MPa}]$

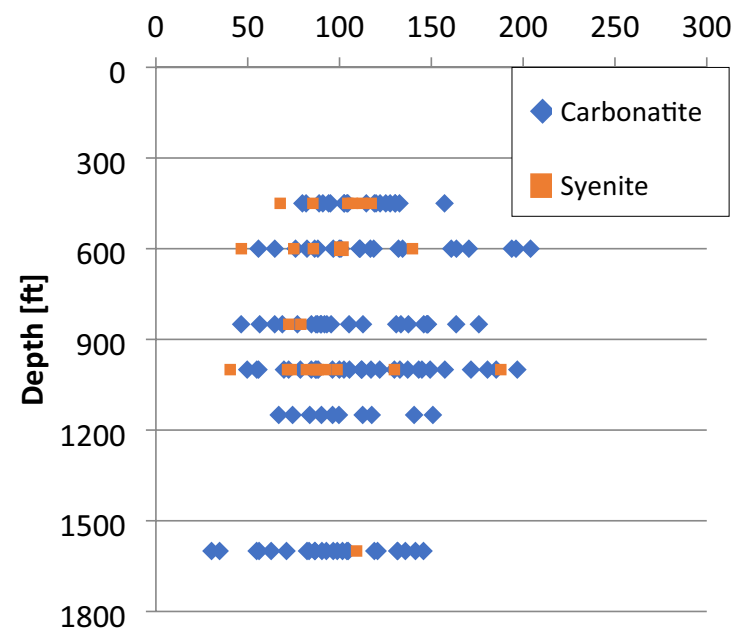

(a)
$\sigma_{t}[\mathrm{MPa}]$

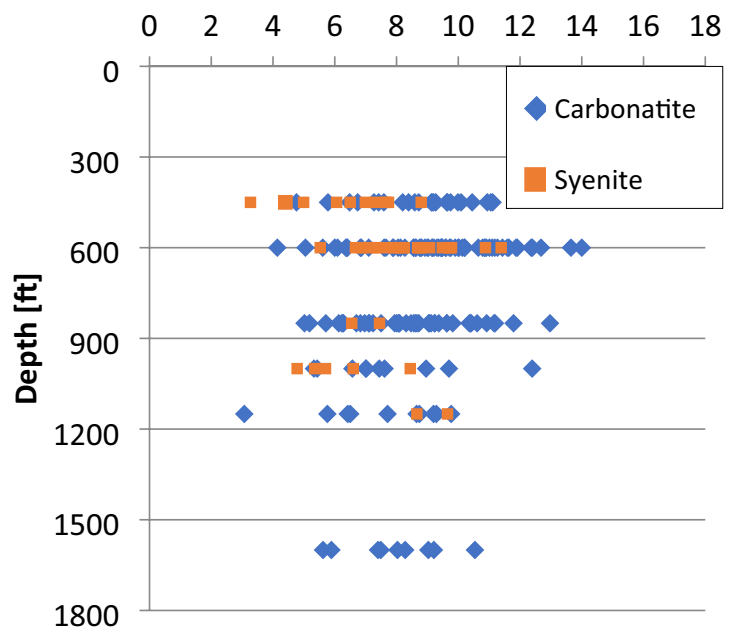

(b)

Fig. 2 Distribution of the results as a function of depth for $\mathbf{a}$ uniaxial compressive strength $\mathbf{b}$ tensile strength

Fig. 3 Distribution of the results as a function of depth for $\mathbf{a}$ Young's Modulus and $\mathbf{b}$ Poisson's ratio
Fig. 4 Box-plot diagrams for the results of a uniaxial compressive and $\mathbf{b}$ tensile strength of syenite, carbonatite and carbonatite-syenite units
$E$ [GPa]

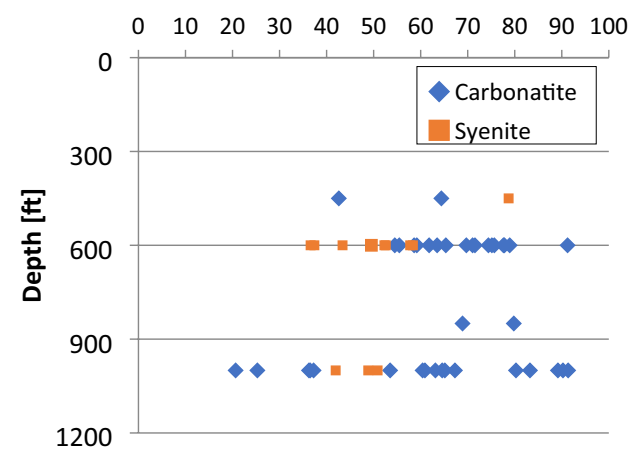

(a)

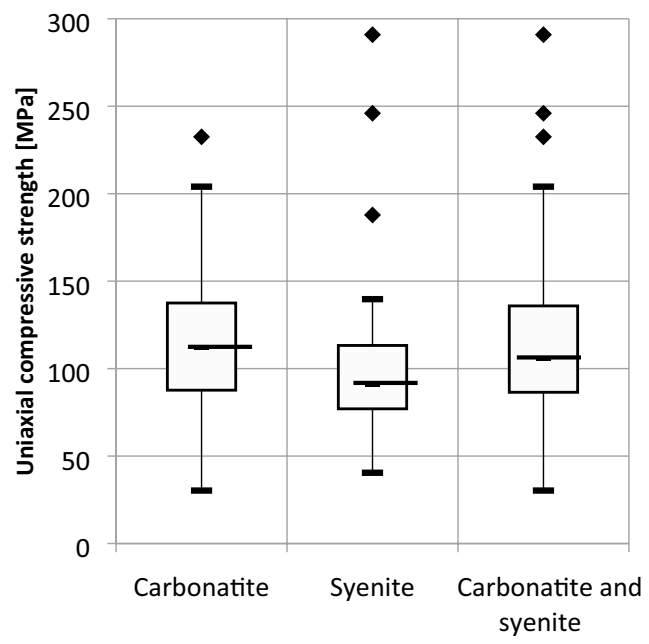

(a)

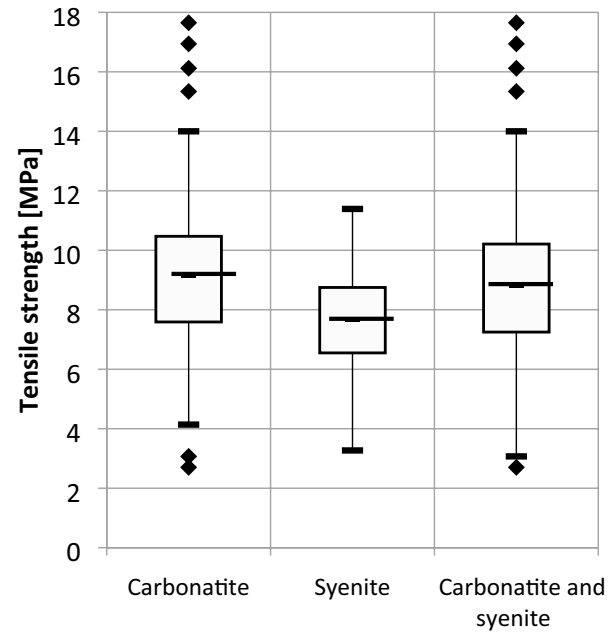

(b) 
The parameters of Mohr-Coulomb and Hoek-Brown failure criteria for the intact rock were also determined from the results of the uniaxial, and triaxial compression tests carried out by the previous campaigns. The experimental results were first grouped together in order to determine the parameters such as $c, \varphi, m_{i}$ and $\sigma_{c i}$ for each of the present lithological units (Table 7). Accordingly, linear regression lines were fitted to the graphs generated from the results of the laboratory tests. The failure envelope curves were subsequently plotted for each of the identified lithological units.
The intact rock failure parameters such as the material constant $m_{i}$ are the parameters mostly defined by the rock type. Variability of such parameters is normally caused by variability in mineral content (lithological heterogeneity), the degree of "particle interlocking", foliation and grain size (texture) $[8,46]$. According to Table 6 , the intact failure parameter values of different carbonatite units, are relatively constant except for the units either with high alteration degrees or with high presence of accessory minerals. Moreover, based on the results of triaxial tests, intact specimens with a more uniform lithological context and
Fig. 5 Box-plot diagrams for the results of a Young's Modulus and b Poisson's Ratio of syenite, carbonatite and carbonatite-syenite units
Table 5 The mean and standard deviation values of uniaxial compressive and tensile strength results for syenite, carbonatite and carbonatite-syenite units

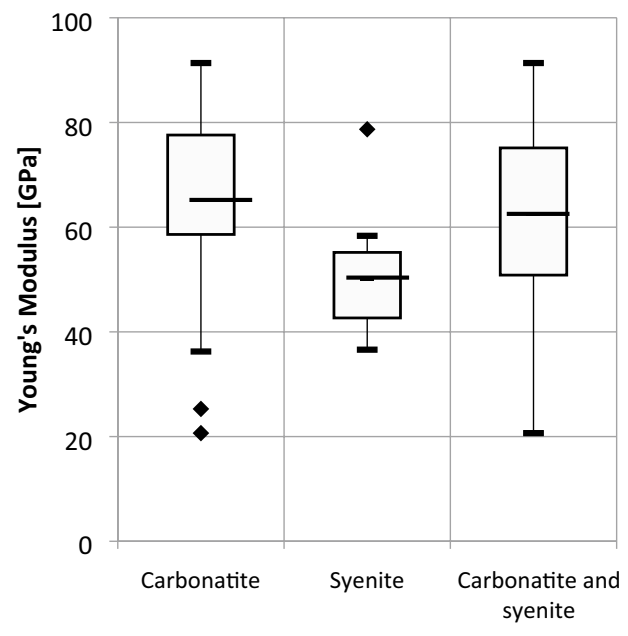

(a)

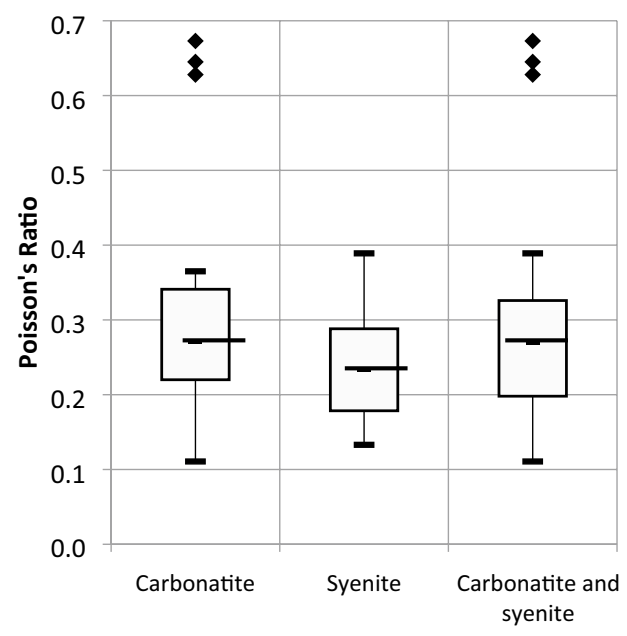

(b)

\begin{tabular}{|c|c|c|c|c|c|c|}
\hline \multirow[t]{2}{*}{ Rock unit } & \multicolumn{3}{|c|}{ Uniaxial compressive strength } & \multicolumn{3}{|c|}{ Tensile strength } \\
\hline & $\sigma_{c \text { Ave. }}[\mathrm{MPa}]$ & s.d [MPa] & $\begin{array}{l}\text { Number of } \\
\text { tests }\end{array}$ & $\sigma_{t \text { Ave. }}[\mathrm{MPa}]$ & s.d [MPa] & $\begin{array}{l}\text { Num- } \\
\text { ber of } \\
\text { tests }\end{array}$ \\
\hline Carbonatite & 113.06 & 35.72 & 153 & 9.05 & 2.06 & 191 \\
\hline Syenite & 90.74 & 23.42 & 25 & 7.53 & 1.79 & 42 \\
\hline $\begin{array}{l}\text { Carbonatite } \\
\text { and syenite }\end{array}$ & 110.36 & 35.46 & 179 & 8.75 & 2.12 & 234 \\
\hline
\end{tabular}

${ }^{*}$ s.d standard deviation

\begin{tabular}{|c|c|c|c|c|c|c|}
\hline \multirow[t]{2}{*}{ Rock unit } & \multicolumn{3}{|c|}{ Young's modulus } & \multicolumn{3}{|c|}{ Poisson's ratio } \\
\hline & $E_{\text {Ave. }}[\mathrm{GPa}]$ & s.d [GPa] & $\begin{array}{l}\text { Number of } \\
\text { tests }\end{array}$ & $v_{\text {Ave }}$ & s.d & $\begin{array}{l}\text { Num- } \\
\text { ber of } \\
\text { tests }\end{array}$ \\
\hline Carbonatite & 67.12 & 14.68 & 36 & 0.26 & 0.07 & 35 \\
\hline Syenite & 48.14 & 7.44 & 11 & 0.24 & 0.07 & 12 \\
\hline $\begin{array}{l}\text { Carbonatite and } \\
\text { syenite }\end{array}$ & 61.41 & 17.19 & 50 & 0.26 & 0.07 & 47 \\
\hline
\end{tabular}

${ }^{*}$ s.d standard deviation

Table 6 The mean and standard deviation values of Young's modulus and Poisson's ratio results for syenite, carbonatite and carbonatitesyenite units 
less concentration of micro cracks, showed higher strength than the specimens with high concentration of accessory minerals, or with a large amount of syenite fragments altered in chlorite.

The test results are then combined in order to compare the failure parameters of the carbonatite and syenite units. Figure 6 presents the obtained Mohr-Coulomb and Hoek-Brown failure envelopes for the groups of carbonatites and syenite rock units while Fig. 7 illustrates the obtained Mohr-Coulomb and Hoek-Brown failure envelopes for the carbonatite-syenite rock unit. The average values of the failure parameters for the three mentioned rock units are reported in Table 8.

According to the presented results in Table 7, the estimated values of failure parameters for carbonatite is slightly higher than syenite, but fairly close to the values obtained for the carbonatite-syenite rock unit.

Even though a slight difference was observed between the calculated strength and deformability parameters of carbonatite and syenite intact units, the carbonatitesyenite provided a quit fair approximation of the two units. Therefore, assuming a homogeneous intact rock containing a random combination of syenite and carbonatite units could provide an agreeable geomechanical description of intact rock for the case of Niobec Mine. Table 9 summarizes the average values to be considered in characterizing the properties of the intact rock at the Niobec mine.

\section{Geomechanical characterization of the rock mass}

It was shown in the previous section that in the scale of intact rock, a homogenous carbonatite-syenite rock rather than considering only a carbonatitic or syenitic

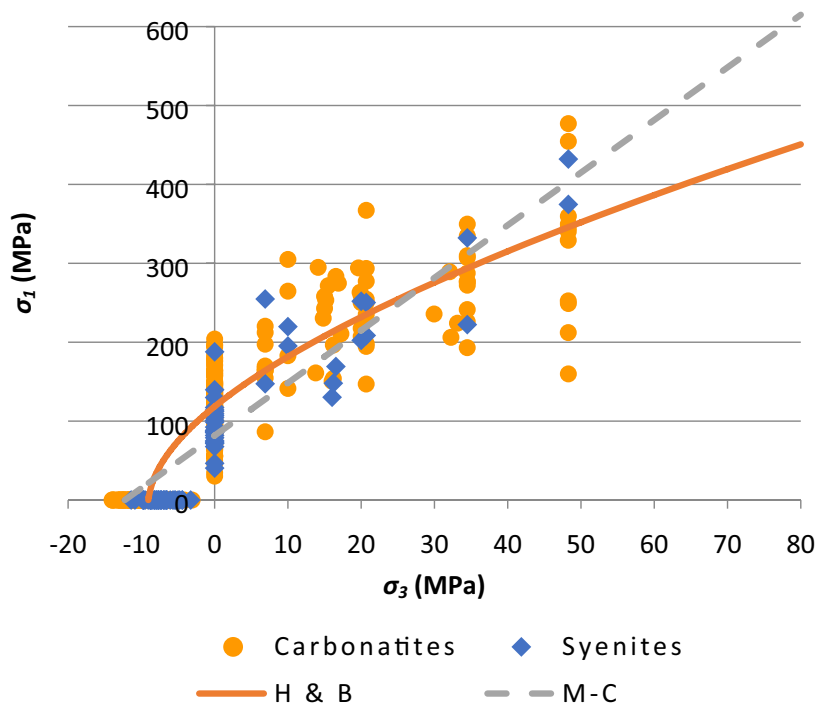

Fig. 7 The combined Hoek-Brown and Mohr-Coulomb failure envelopes for the carbonatite and the syenite

intact rock provides a more realistic approximation for the existing rock at the Niobec Mine. This assumption is aligned with the findings of local site characterization programs conducted during the deposit exploitation which emphasized that the nature of rock mass at the Niobec Mine is too complex to be discretized geomechanically hence the observed irregularities in the quality of intact rock units should be considered to occur in local scales [34, 35]. In this part, the same hypothesis is examined in the rock mass scale to see whether the results would support the consideration of a unified carbonatite-syenite rock mass unit for the Niobec Mine or not. Geomechanical characterization of rock mass, can be accomplished through using the obtained results
Fig. 6 Hoek-Brown and MohrCoulomb failure envelope for $\mathbf{a}$ Carbonatite and $\mathbf{b}$ Syenite

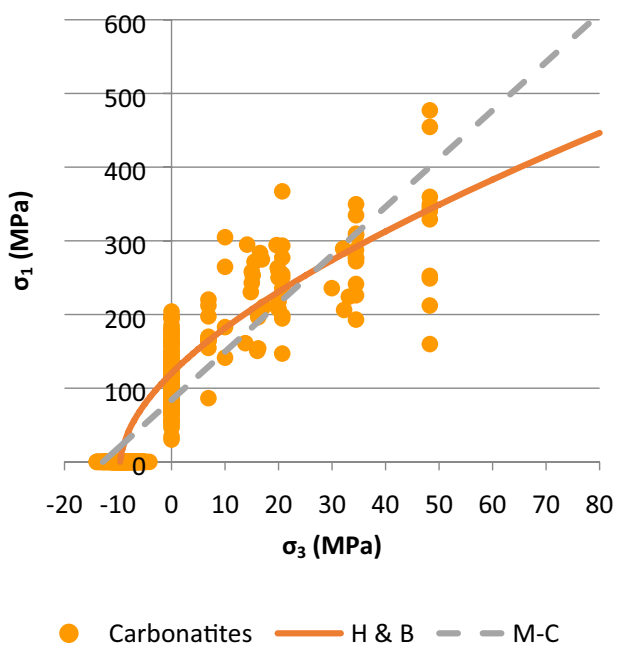

(a)

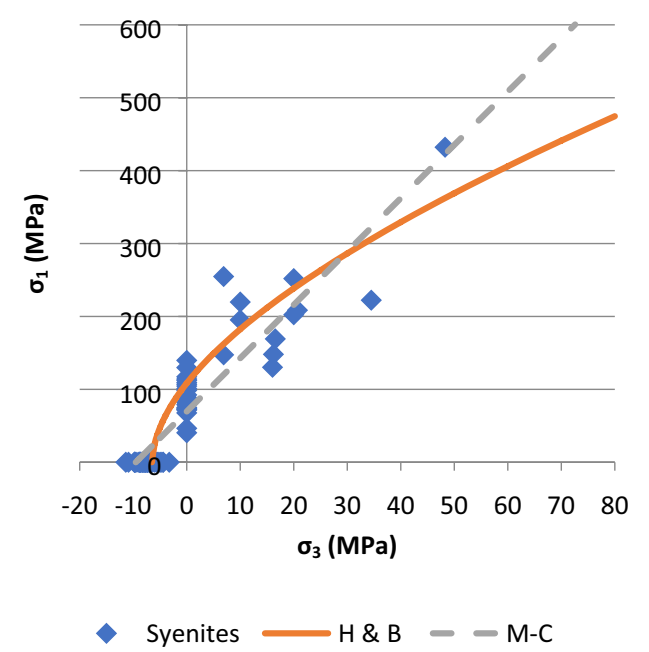

(b)

SN Applied Sciences 
Table 7 The parameters of Hoek-Brown and MohrCoulomb failure criteria for each lithological unit

\begin{tabular}{|c|c|c|c|c|c|c|}
\hline \multirow{3}{*}{$\begin{array}{l}\text { Test campaigns (year) and } \\
\text { lithological units }\end{array}$} & \multicolumn{6}{|c|}{ Failure criteria } \\
\hline & \multicolumn{3}{|c|}{ Mohr-Coulomb } & \multicolumn{3}{|c|}{ Hoek-Brown } \\
\hline & $c[\mathrm{MPa}]$ & $\varphi\left[{ }^{\circ}\right]$ & $\mathrm{R}^{2}$ & $m_{i}$ & $\sigma_{c i}[\mathrm{MPa}]$ & $\mathrm{R}^{2}$ \\
\hline \multicolumn{7}{|l|}{ Labrie (1987) } \\
\hline C5 & 16.72 & 56.56 & 0.8792 & 15.24 & 139.53 & 0.7747 \\
\hline $\mathrm{C} 3 \mathrm{~A}$ & 12.12 & 55.03 & 0.9259 & 16.50 & 115.78 & 0.8722 \\
\hline $\mathrm{C} 3 \mathrm{C}$ & 12.68 & 47.71 & 0.8794 & 8.89 & 83.69 & 0.8746 \\
\hline $\mathrm{C} 3 \mathrm{~N}$ & 14.90 & 56.00 & 0.8834 & 14.79 & 120.48 & 0.8185 \\
\hline Sy intact & 13.21 & 51.86 & 0.8549 & 10.71 & 93.75 & 0.8906 \\
\hline Sy altered & 8.67 & 47.24 & 0.8818 & 10.62 & 64.92 & 0.9224 \\
\hline \multicolumn{7}{|l|}{ Labrie (1997) } \\
\hline C5 & 12.45 & 53.03 & 0.8488 & 14.51 & 115.28 & 0.7234 \\
\hline $\mathrm{C} 3 \mathrm{~N}$ & 17.33 & 53.29 & 0.8401 & 13.46 & 148.59 & 0.6834 \\
\hline Sy intact & 14.51 & 51.02 & 0.8939 & 11.50 & 115.80 & 0.9101 \\
\hline Sy altered & 14.30 & 53.77 & 0.963 & 15.03 & 129.18 & 0.9437 \\
\hline \multicolumn{7}{|l|}{ Desbiens (1997) } \\
\hline C5 & 17.71 & 48.42 & 0.6794 & 32.49 & 87.62 & 0.8581 \\
\hline C3A & 30.85 & 29.66 & 0.7218 & 4.64 & 117.86 & 0.663 \\
\hline C3B & 18.95 & 45.50 & 0.7269 & 17.35 & 108.44 & 0.8198 \\
\hline $\mathrm{C} 3 \mathrm{~N}$ & 16.93 & 46.22 & 0.742 & 12.29 & 107.93 & 0.8171 \\
\hline C3NA & 33.16 & 30.43 & 0.435 & 3.76 & 139.72 & 0.1985 \\
\hline C3NB & 25.47 & 46.23 & 0.8138 & 14.48 & 150.62 & 0.7163 \\
\hline Sy intact & 16.26 & 47.29 & 0.8118 & 19.76 & 108.95 & 0.7377 \\
\hline Sy altered & 13.97 & 48.54 & 0.943 & 21.33 & 94.30 & 0.9631 \\
\hline \multicolumn{7}{|l|}{ Corthésy (2000) } \\
\hline C5S & 15.46 & 45.86 & 0.7835 & 10.93 & 107.40 & 0.7487 \\
\hline $\mathrm{C} 3 \mathrm{C}$ & 15.82 & 46.91 & 0.8573 & 12.71 & 112.10 & 0.71 \\
\hline \multicolumn{7}{|l|}{ Lajoie (2010) } \\
\hline C5 & 35.15 & 27.03 & 0.8549 & 4.49 & 113.68 & 0.71 \\
\hline C3A & 16.42 & 46.59 & 0.8668 & 14.39 & 109.39 & 0.93 \\
\hline C3AS & 21.07 & 34.18 & 0.7351 & 6.73 & 91.01 & 0.5693 \\
\hline C3B & 17.80 & 44.02 & 0.8926 & 13.16 & 107.37 & 0.9376 \\
\hline
\end{tabular}

${ }^{*} R^{2}=$ Regression coefficient
Table 8 The values of HoekBrown and Mohr-Coulomb failure parameters

\begin{tabular}{|c|c|c|c|c|c|c|}
\hline \multirow[t]{3}{*}{ Rock unit } & \multicolumn{6}{|c|}{ Failure criteria } \\
\hline & \multicolumn{3}{|c|}{ Mohr-Coulomb } & \multicolumn{3}{|c|}{ Hoek-Brown } \\
\hline & $c[\mathrm{MPa}]$ & $\varphi\left[{ }^{\circ}\right]$ & $\mathrm{R}^{2}$ & $m_{i}$ & $\sigma_{c i}[\mathrm{MPa}]$ & $\mathrm{R}^{2}$ \\
\hline Carbonatite & 16.40 & 47.32 & 0.7764 & 12.45 & 120.25 & 0.6845 \\
\hline Syenite & 12.88 & 49.41 & 0.8820 & 16.60 & 108.42 & 0.8139 \\
\hline $\begin{array}{l}\text { Carbonatite and } \\
\text { syenite }\end{array}$ & 15.82 & 47.65 & 0.7872 & 13.01 & 118.53 & 0.7012 \\
\hline
\end{tabular}

\subsection{Probabilistic estimation of rock mass geomechanical parameters}

Hoek-Brown failure criterion is used in conjunction with the Geological Strength Index (GSI) to estimate the geomechanical parameters of the syenitic, carbonatitic 
Table 9 The mean values geomechanical parameters for the carbonatite-syenite intact rock unit

\begin{tabular}{ll}
\hline Geomechanical properties & carbonatite-syenite unit \\
\hline Uniaxial compressive strength & $\sigma_{c \text { (mean) }}=110.4 \mathrm{MPa}$ \\
Tensile strength & $\sigma_{t(\text { mean })}=8.8 \mathrm{MPa}$ \\
Young's modulus & $E_{(\text {mean })}=61.4 \mathrm{GPa}$ \\
Poisson's ratio & $U_{\text {(mean) }}=0.26$ \\
Cohesion (Mohr-Coulomb) & $c=15.8 \mathrm{MPa}$ \\
Friction angle (Mohr-Coulomb) & $\varphi=47.7^{\circ}$ \\
$\sigma_{c i}$ (Hoek \& Brown) & $\sigma_{c i}=118.5 \mathrm{MPa}$ \\
$m_{i}$ (Hoek \& Brown) & $m_{i}=13.0$ \\
Unit weight of Rock & $\gamma=2.839 \mathrm{t} / \mathrm{m}^{3}$ \\
\hline
\end{tabular}

and carbonatite-syenite rock mass. Accordingly, mean and standard deviation values of the intact UCS, the Hoek-Brown material constant $\left(m_{i}\right)$ and the intact Young's modulus $\left(E_{i}\right)$ of syenite, carbonatite and the carbonatite-syenite rock units are adopted from the intact rock characterization results (Table 10). The mean GSI value and the corresponded standard deviation of the rock mass were adopted from the study conducted by Lavoie [37]. Based on the concentration of discontinuities and the number of joint sets identified within the carbonatite-syenite unit, the rock mass was recognized to have a blocky structure with rough and slightly altered joint surface condition. Therefore, to assign an appropriate value of GSI to the rock mass at the Niobec Mine, the calculated value of $\mathrm{RMR}_{89}$ as equal to 71 was used (as reported by Golder [34] and Lajoie [35]) and the GSI was calculated as 74 based on the conversion formula provided by Hoek and Brown [3]. It should be noted that estimating the GSI value from $\mathrm{RMR}_{89}$ might be unreliable, especially for poor quality rock masses and for rocks with lithological peculiarities that cannot be easily incorporated in the RMR classification [9]. However, in this case, due to the high quality of rock mass and lack of GSI data resulted from direct GSI estimations, the above-mentioned conversion formula is used.

Since the reported $\mathrm{RMR}_{89}$ value was estimated for the entire rock mass and no GSI value was available separately for different units within the rock mass, the same GSI value of 74 was considered for each syenite and carbonatite units for further geomechanical calculations (Table 10). These values are considered as random inputs when calculating the geomechanical parameters.

The Kolmogorov - Smirnov statistical test was applied on the above-mentioned parameters to assign the best-fitted probability distributions function (PDF) to each parameter. According to the results of Akaike Information Criterion (AIC) goodness of fit test, Weibull and Normal distributions were determined to be the most appropriate statistical distributions for the parameters. However, for the sake of simplicity, normal PDFs were chosen to be assigned to the parameters. Assuming normal distribution function to describe the random characteristics of the geomechanical parameters is consistent with the suggestions made by many studies e.g. $[6,20,22,26$, and 47].

To eliminate generation of negative and/or false values, the normal PDFs were truncated by using the actual reported minimum and maximum values. Figures $8 \mathrm{a}-\mathrm{c}$ illustrate examples of the truncated PDF plots for intact rock material properties of the carbonatite-syenite rock mass.

Subsequently, the MCS method was applied to calculate the Hoek-Brown strength and deformability parameters of each rock mass type through Eqs. 1-6 [9].

$m_{b}=m_{i} \mathrm{e}^{\left(\frac{G S I-100}{28-14 D}\right)}$

$S=\mathrm{e}^{\left(\frac{G S I-100}{9-3 D}\right)}$

$a=\frac{1}{2}+\frac{1}{6}\left(e^{\frac{-G S I}{15}}-e^{\frac{-20}{3}}\right)$

$\sigma_{c m}=\sigma_{c i} s^{a}$

$\sigma_{t}=\frac{s \sigma_{c i}}{m_{b}}$

$E_{r m}=E_{i}\left(0.02+\frac{1-\frac{D}{2}}{1+e^{\left(\frac{60+15 D-G S I}{11}\right)}}\right)$

where $D$ represents the degree of disturbance of the rock mass (ranging from 0 to 1 for undisturbed in-situ rock masses to highly disturbed rock masses) [9]. Since the rock
Table 10 The mean and standard deviation values of geomechanical parameters for the syenite, carbonatite and carbonatite-syenite rock

\begin{tabular}{|c|c|c|c|c|c|c|}
\hline & \multicolumn{2}{|c|}{ carbonatite-syenite } & \multicolumn{2}{|l|}{ Syenite } & \multicolumn{2}{|c|}{ Carbonatite } \\
\hline & Min-Max & Mean-S.d & Min-Max & Mean-S.d & Min-Max & Mean-S.d \\
\hline$U C S_{\text {intact }}$ & $30.3-204$ & $110.4-35.5$ & $40.5-139.7$ & $90.7-23.4$ & $30.3-204$ & $113.1-35.7$ \\
\hline GSI & $36-100$ & $74.3-8.2$ & $36-100$ & $74.3-8.2$ & $36-100$ & $74.3-8.2$ \\
\hline$m_{i}$ & $4.5-22$ & $13.0-4.3$ & $10.5-22$ & $16.6-4.7$ & $4.5-24$ & $12.4-4.1$ \\
\hline$E_{i}$ & 20.7-91.4 & $61.4-17.2$ & $36.6-58.3$ & $48.1-7.4$ & $36.2-91.4$ & $67.1-14.7$ \\
\hline$u$ & $0.11-0.39$ & $0.26-0.07$ & $0.13-0.39$ & $0.24-0.07$ & $0.11-0.73$ & $0.26-0.07$ \\
\hline
\end{tabular}




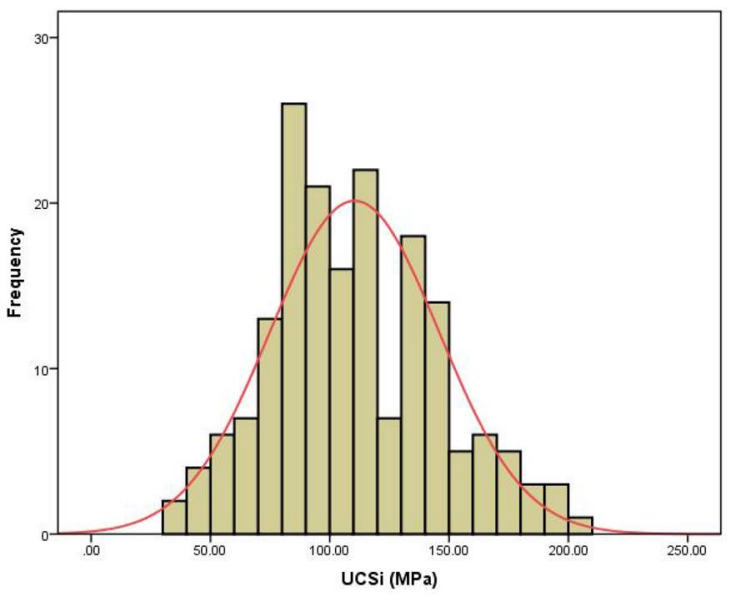

(a)

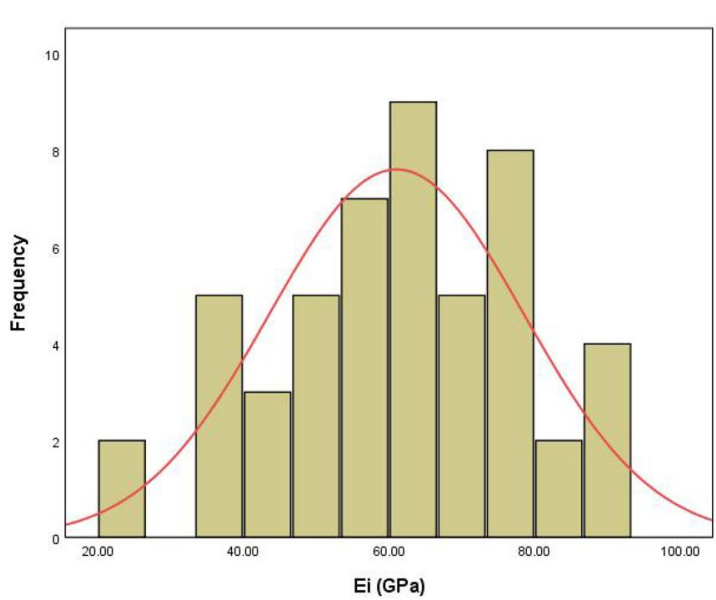

(c)

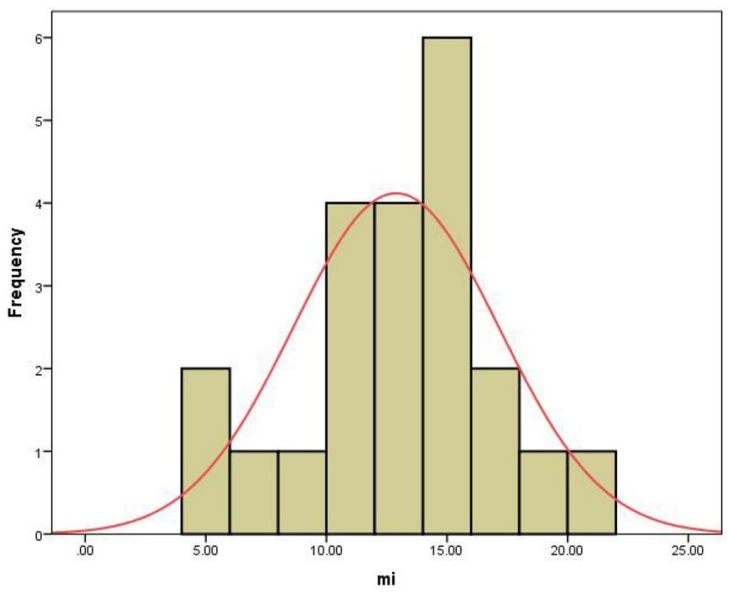

(b)

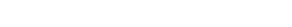


Table 11 The mean values and standard deviations of geomechanical parameters for the syenite, carbonatite and carbonatite-syenite rock mass

\begin{tabular}{|c|c|c|c|c|c|c|c|c|c|c|c|c|c|}
\hline \multirow[t]{2}{*}{ PDF } & & \multicolumn{4}{|c|}{ Carbonatite-syenite } & \multicolumn{4}{|c|}{ Syenite } & \multicolumn{4}{|c|}{ Carbonatite } \\
\hline & & Mean & S.d & Min & Max & Mean & S.d & Min & Max & Mean & S.d & Min & Max \\
\hline$m_{b}$ & Gamma & 5.45 & 2.32 & 0.88 & 19.2 & 6.83 & 2.41 & 1.69 & 19.17 & 5.28 & 2.25 & 0.925 & 18.56 \\
\hline$s$ & Log-normal & 0.08 & 0.07 & 0.00 & 0.97 & 0.057 & 0.092 & 0.00 & 0.979 & 0.086 & 0.09 & 0.001 & 0.99 \\
\hline$a$ & Log-normal & 0.501 & 0.0008 & 0.500 & 0.508 & 0.501 & 0.0008 & 0.500 & 0.508 & 0.501 & 0.0008 & 0.500 & 0.509 \\
\hline$\sigma_{c}$ & Inversed-gaussian & 29.5 & 17.20 & 2.33 & 185.2 & 24.06 & 13.03 & 2.46 & 114.56 & 30.09 & 17.36 & 1.84 & 162.9 \\
\hline$\sigma_{t}$ & Log-normal & 1.64 & 1.44 & 0.05 & 22.6 & 1.000 & 0.76 & 0.045 & 8.175 & 1.73 & 1.50 & 0.049 & 15.89 \\
\hline$E_{r m}$ & Normal & 47.2 & 14.25 & 8.70 & 88.3 & 37.44 & 7.48 & 9.61 & 56.81 & 51.82 & 12.98 & 10.34 & 88.89 \\
\hline
\end{tabular}

\subsection{Deterministic estimation of rock mass geomechanical parameters}

The RocData 5.0 software [49], was used to provide a deterministic estimation of the carbonatite-syenite rock mass parameters through the calculated mean values of the input parameters (Table 10). Similarly, Eqs. 1-6 were used by the software and the factor $D$ was considered equal to 0 [50]. The failure envelopes of the Hoek-Brown criterion, traced for the calculated parameters, are presented in Fig. 12. Table 12 presented the average estimated values of strength and deformability parameters for the carbonatite-syenite rock mass.

\section{Discussion on the geomechanical characterization results}

Studying the results of geological and geomechanical characterizations, emphasizes the necessity of adopting an accurate interpretation of data considering both lithological and geomechanical descriptions of a rock mass. In fact, lithological heterogeneity shouldn't provide a misleading indication on the presence of geomechanical variety throughout that rock mass.

In this regard, studying the field and laboratory tests results of different test campaigns at the Niobec Mine, revealed that lithological heterogeneity rather than depth was responsible for the variation in geomechanical properties of the three main identified rock units. Studying the results proved that the largest variations in geomechanical parameters belong to the carbonatitic lithological units either with maximum separation from the syenitic lithological units or with intense alteration to chlorite. In fact, the resulted variability in strength and deformability parameters of intact samples was determined to be significantly defined by the degree of carbonatite alteration. Furthermore, geomechanical characterization of intact samples identified the carbonatitic units with a better quality than syenitic units. Determination of the Mohr-Coulomb and Hoek-Brown failure parameters for each constituent lithological unit and subsequently each rock unit (Tables 7 and 8 ), revealed that the strength of different carbonatitic lithological units was relatively constant except for the units either with intense alteration or with high presence of accessory minerals. In fact, according to the results of previously conducted triaxial tests, it was concluded that high concentrations of accessory minerals within the intact samples, presence of a contact between two different lithological units and presence of large quantities of altered syenite fragments to chlorite could result in reduction of rock strength compared to equivalent samples with more uniform lithological context and less concentration of micro cracks.

However, in geomechanical perspective, the observed difference between the calculated strength and deformability parameters of carbonatite and syenite units, wouldn't be sufficient enough to justify the assumption of considering them as distinguished units within the intact rock; however, the carbonatite-syenite rock unit provided a quite reasonable approximation of geomechanical properties of the two aforementioned units. Besides, findings of local site characterization programs during the deposit exploitation phases, demonstrated that the nature of rock mass at the Niobec Mine is too complex to be discretized geomechanically and the captured irregularities in the quality of intact rock units are considered to occur in local scales $[34,35]$. Therefore, assuming a homogeneous intact rock containing a random combination of syenite and carbonatite rock units could provide a valid geomechanical description of intact rock for the case of Niobec Mine.

In the rock mass scale, estimation of geomechanical parameters separately for syenite, carbonatite and carbonatite-syenite rock units also determined the quality of carbonatite rock mass to be slightly higher than syenite but fairly close to the quality of the carbonatite-syenite rock mass. Even the dispersions of the estimated strength and deformability parameters, were obtained to be very similar between carbonatite and carbonatite-syenite rock masses (Table 11). The obtained results of rock mass 


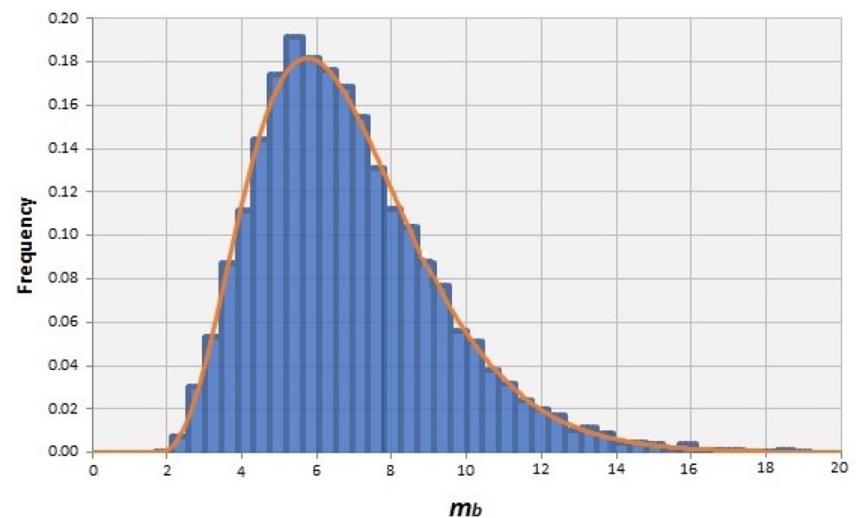

(a)

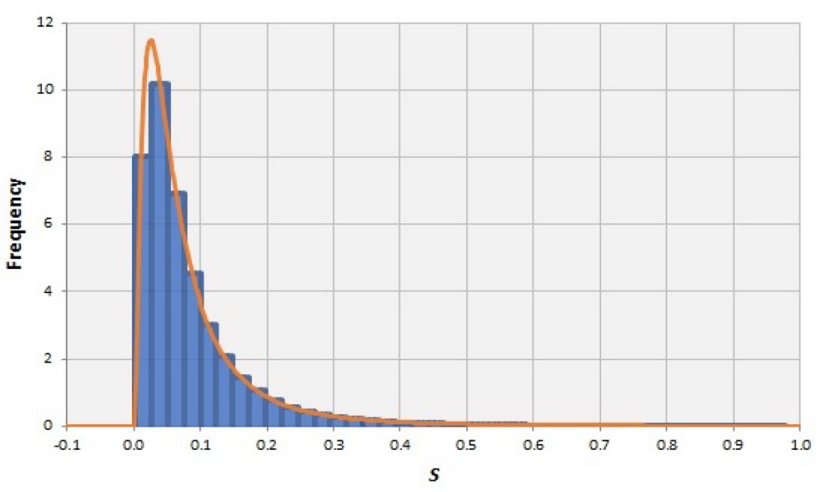

(c)

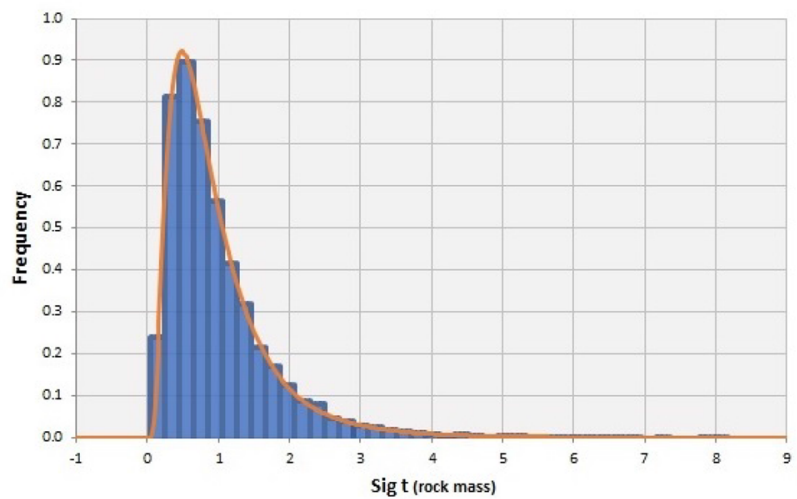

(e)

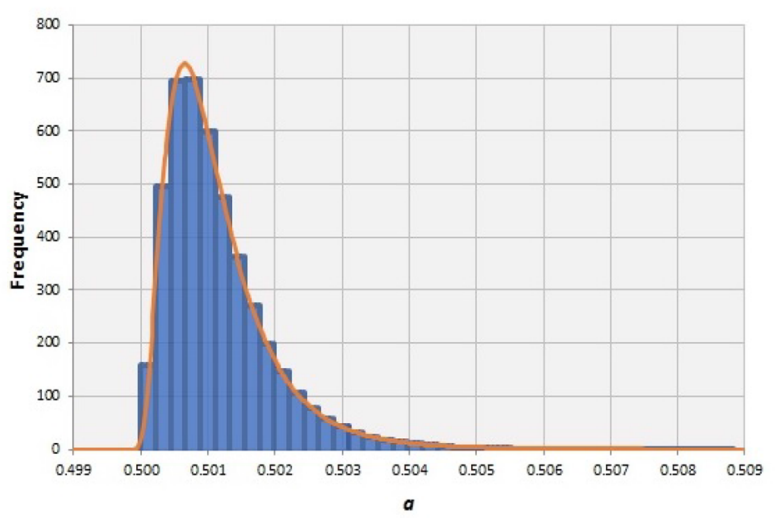

(b)

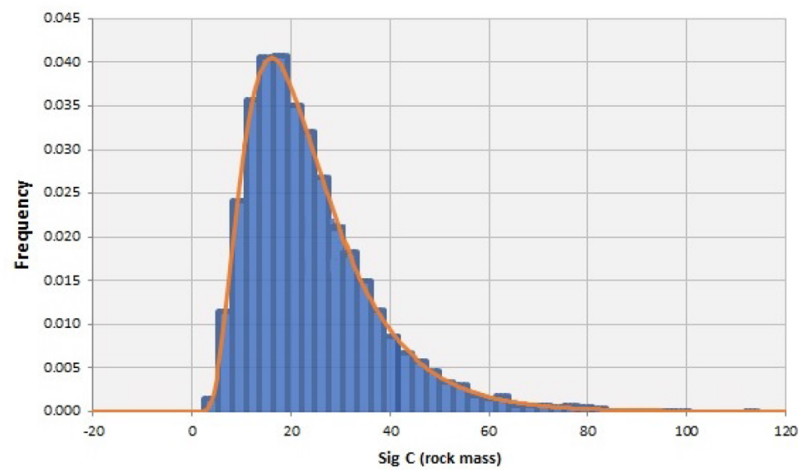

(d)

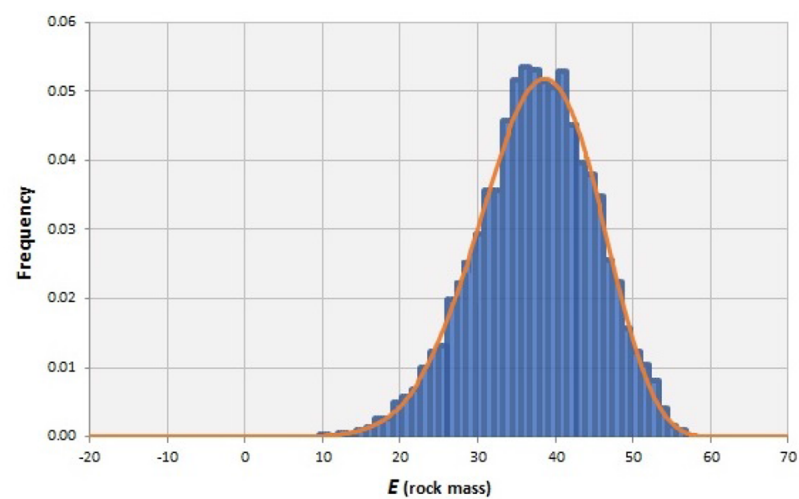

(f)

Fig. 9 Histograms and the best-fitted PDF of the geomechanical parameters of the syenite rock mass

geomechanical characterization in this study, was based on estimating the GSI value using $\mathrm{RMR}_{89}$ conversion method. It should be noted that even though this conversion method has been conventionally used in many similar studies, it can be unreliable, particularly for poor quality rock masses and for rocks with lithological peculiarities that cannot be easily incorporated in the RMR calculations. Therefore, it is recommended to estimate the GSI directly and not from the RMR classification. Moreover, due to the lack of data, a same value of GSI had to be considered for all the three identified rock mass units which imposed a limit upon the accuracy of the obtained results through oversimplifying the calculation of rock mass geomechanical parameters for different units.

Ultimately, comparison between the results of deterministic and probabilistic estimation of geomechanical 


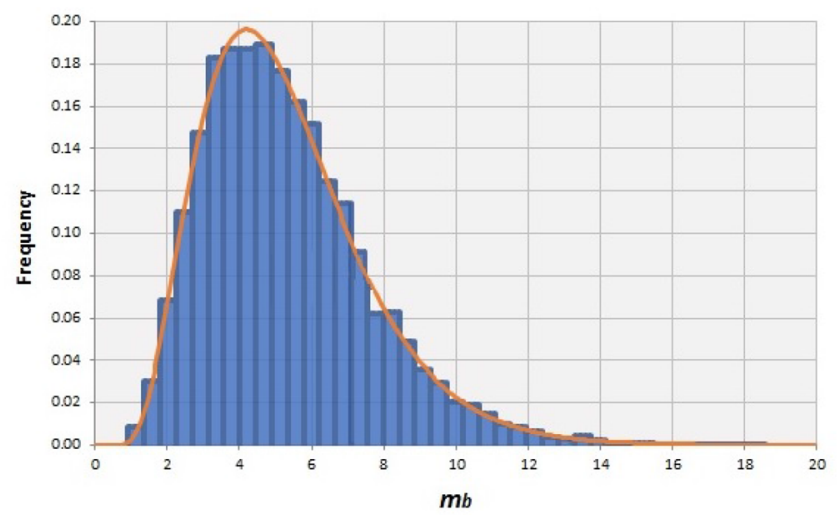

(a)

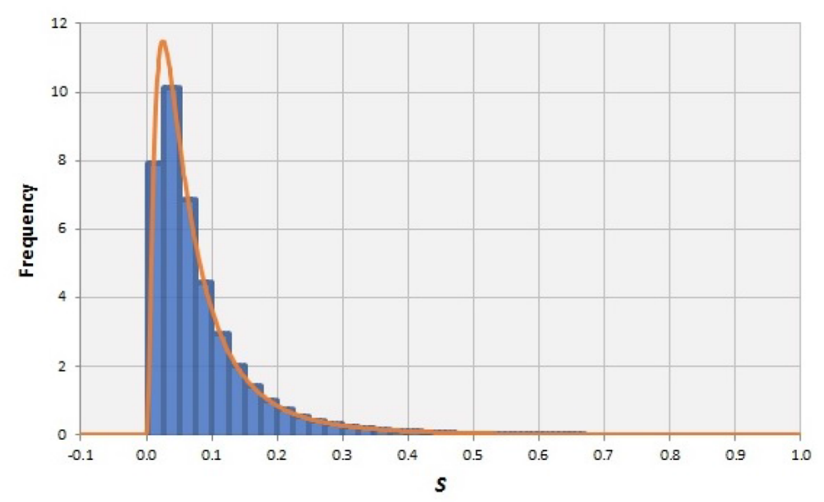

(c)

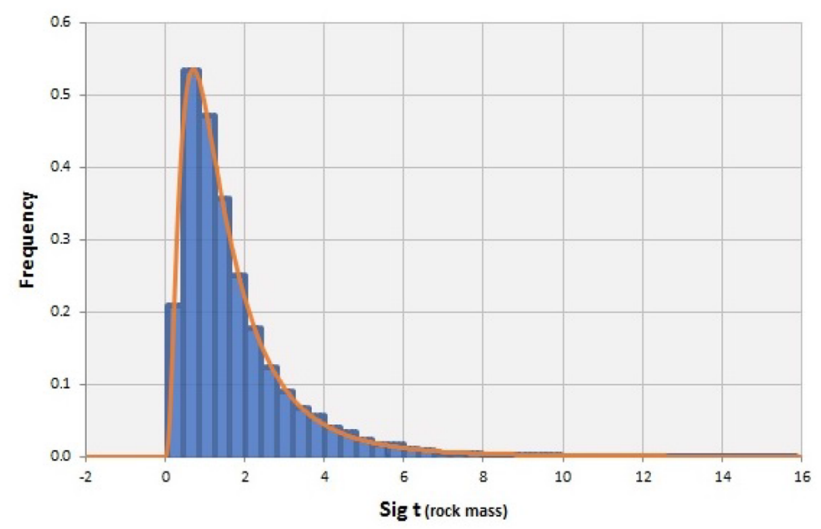

(e)

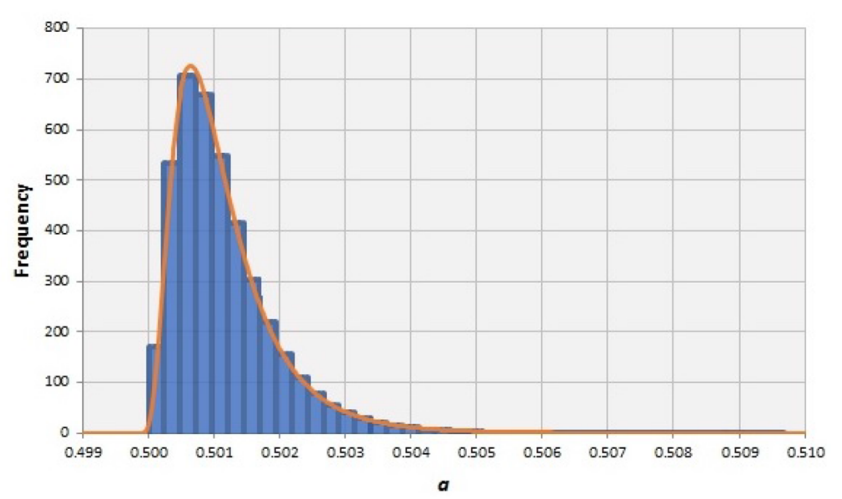

(b)

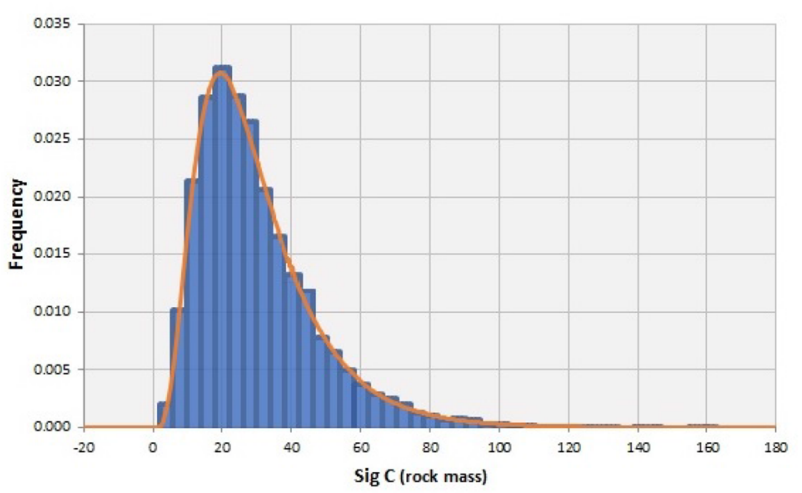

(d)

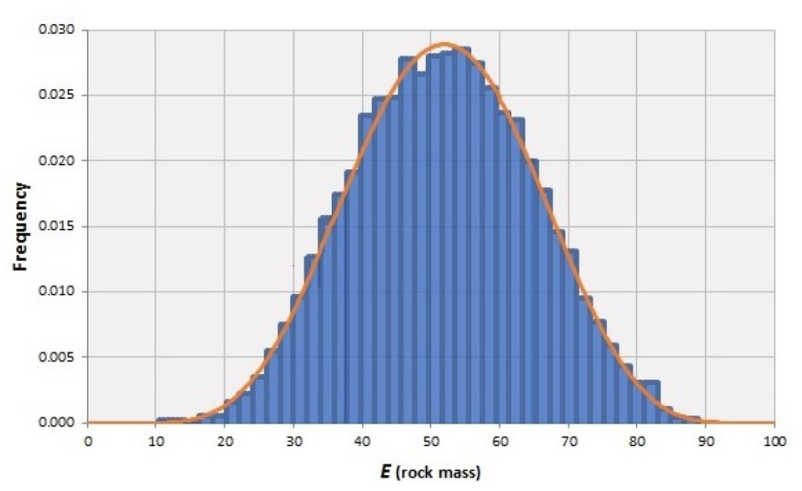

(f)

Fig. 10 Histograms and the best-fitted PDF of the geomechanical parameters of the carbonatite rock mass

parameters for the particular case of carbonatitesyenite rock mass, proved the significant presence of variability associated to each parameter and inability of conventional deterministic approaches to address them entirely (Table 12). Conventional deterministic approaches cannot capture the variability of rock mass properties since they assign a single mean value to the parameters instead of defining them through probability distribution functions (which consider the mean and standard deviation values). This simplification not only ignores the inherent variable nature of rock mass, but also by assuming a better rock mass quality in terms of strength and stiffness produces unreliable and unclear results that could be misleading in subsequent rock mechanics analyses. It is hence recommended to incorporate uncertainties associated with the variability of 


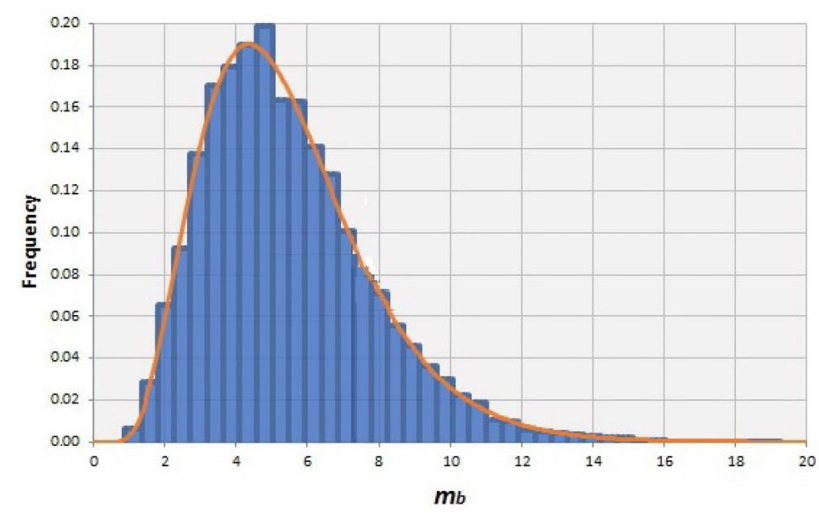

(a)

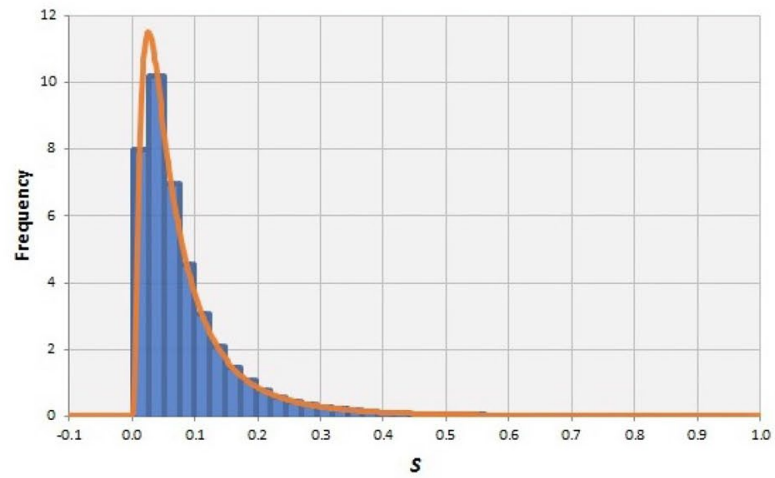

(c)

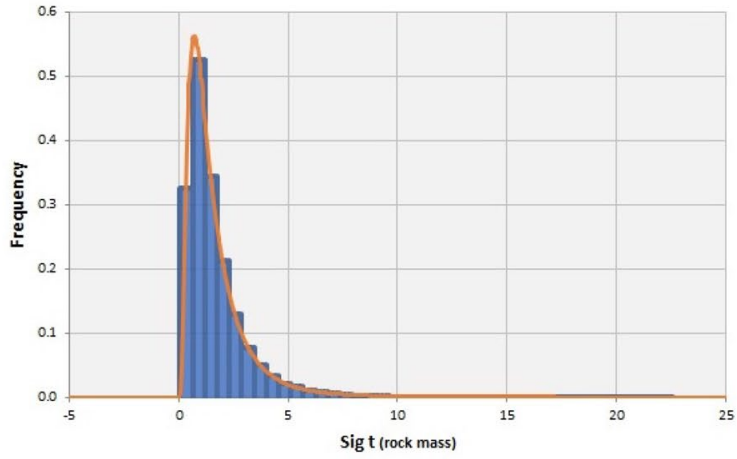

(e)

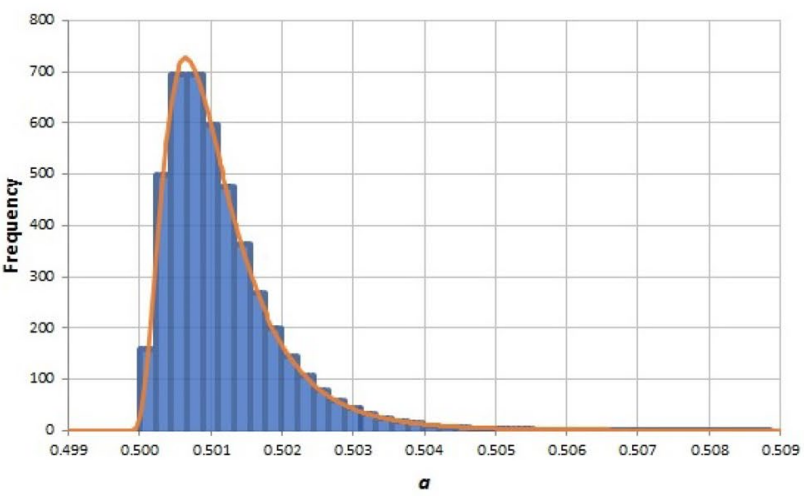

(b)

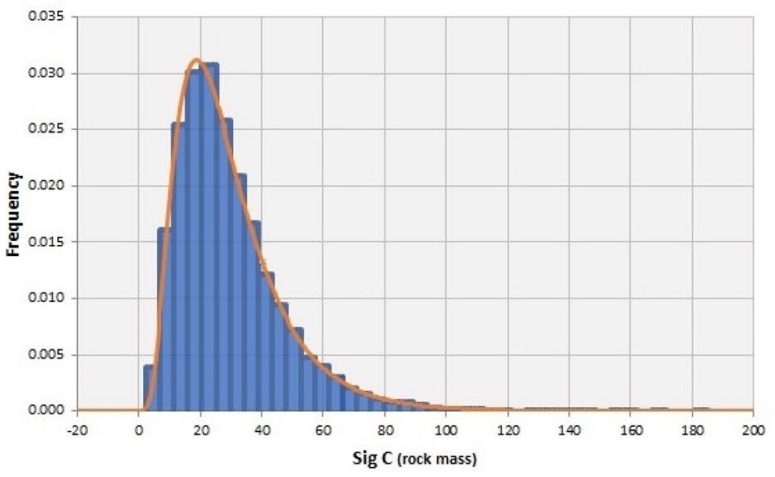

(d)

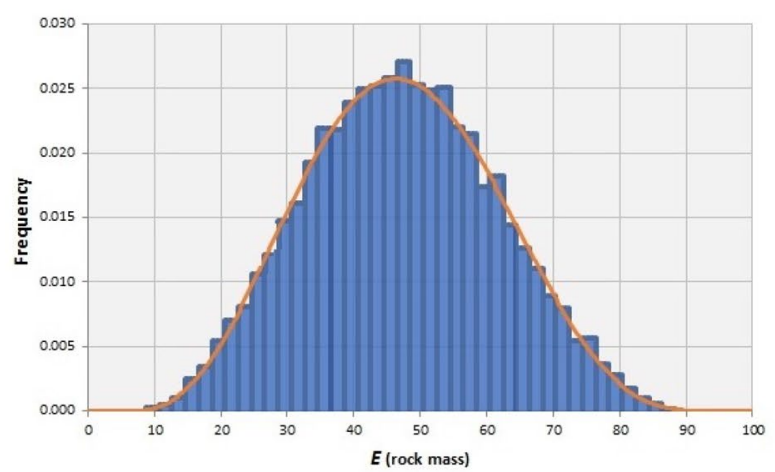

(f)

Fig. 11 Histograms and the best-fitted PDF of the geomechanical parameters of the carbonatite-syenite rock mass

rock mass parameters into consideration to ensure that the actual behavior of rock mass is properly reflected.

\section{Conclusion}

The results of previously conducted geomechanical and geological field and laboratory tests at the Niobec Mine (Quebec, Canada) were combined to characterize the heterogeneous rock mass by considering the lithological and mechanical properties of identified lithological units' constituents. The aim of this study was to find a reasonable agreement between the geomechanical parameters in relation to the extensive lithological variability for describing the rock mass properties.

The results of intact rock characterization indicated that the carbonatite-syenite rock unit could be considered as an appropriate representative lithology to define 

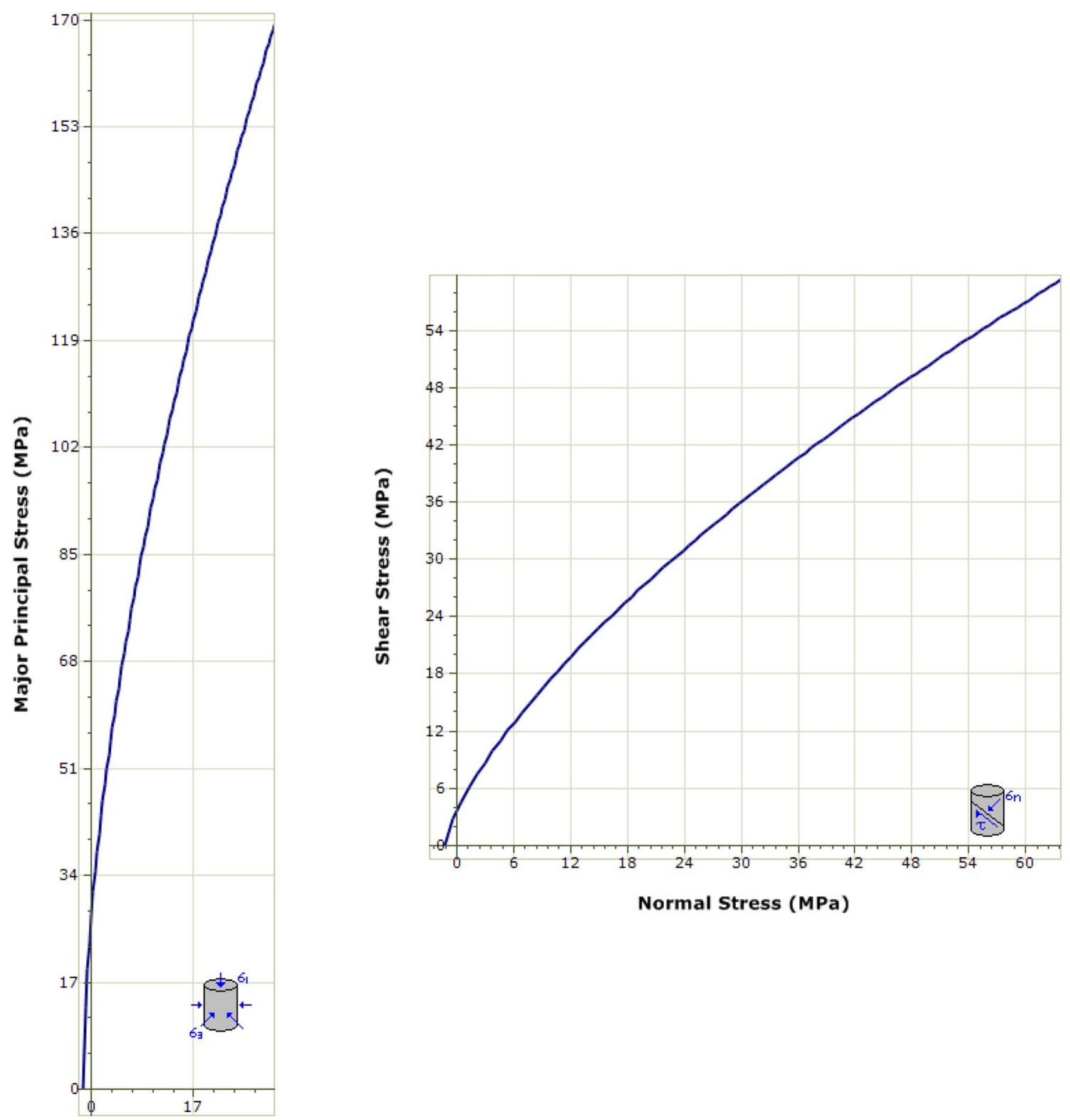

Minor Principal Stress (MPa)

Fig. 12 Hoek-Brown failure envelope and the mean values of geomechanical parameters

Table 12 Deterministic calculation of the Hoek-Brown and Mohr-Coulomb failure constants for the carbonatite-syenite rock mass

\begin{tabular}{llllll}
\hline$m_{b}$ & $s$ & $a$ & $\begin{array}{l}\sigma_{t} \\
{[\mathrm{MPa}]}\end{array}$ & $\begin{array}{l}\sigma_{c} \\
{[\mathrm{MPa}}\end{array}$ & $\begin{array}{l}\sigma_{c m} \\
{[\mathrm{MPa}]}\end{array}$ \\
\hline 5.137 & 0.056 & 0.501 & 1.284 & 27.872 & 41.039 \\
\hline
\end{tabular}

the rock mass geomechanical properties. Furthermore, estimated rock mass geomechanical parameters for syenitic, carbonatitic and carbonatitic-syenitic units also indicated that considering the carbonatite-syenite rock mass instead of trying to distinguish the syenite and the carbonatite as separate units provide a reasonable and

\section{SN Applied Sciences}


reliable approximation of the geomechanical quality of rock mass at the Niobec Mine. Moreover, consideration of the carbonatite-syenite rock unit to represent the entire rock mass provides a good agreement between both the geomechanical and geological perspectives. Finally, the use probabilistic approaches instead of conventional deterministic methods in rock mass geomechanical characterization programs are highly recommended since a more realistic portray of the intrinsic nature of rock materials is depicted by considering the inherent variability associated to the geomechanical parameters.

Acknowledgements The authors would like to acknowledge the funding received by a grant from Natural Sciences and Engineering Research Council of Canada (NSERC) (CRDPJ 469057-14) for this study. We also thank the personnel at the Niobec Mine for their assistance.

Fundings The authors have no relevant financial or non-financial interests to disclose This study was funded by a grant from Natural Sciences and Engineering Research Council of Canada (NSERC) (CRDPJ 469,057-14).

\section{Declarations}

Conflict of interest The authors declare that they have no conflict of interest.

Open Access This article is licensed under a Creative Commons Attribution 4.0 International License, which permits use, sharing, adaptation, distribution and reproduction in any medium or format, as long as you give appropriate credit to the original author(s) and the source, provide a link to the Creative Commons licence, and indicate if changes were made. The images or other third party material in this article are included in the article's Creative Commons licence, unless indicated otherwise in a credit line to the material. If material is not included in the article's Creative Commons licence and your intended use is not permitted by statutory regulation or exceeds the permitted use, you will need to obtain permission directly from the copyright holder. To view a copy of this licence, visit http://creativecommons. org/licenses/by/4.0/.

\section{References}

1. Brady BHG, Brown ET (2006) Rock Mechanics for underground mining, 3rd edn. Springer, Dordrecht, the Netherlands

2. Villaescusa E. (2014). Geotechnical design for sublevel open stoping. CRC Press. ISBN 978-1-4822-1188-7.

3. Hoek E, Brown ET (1997) Practical estimates of rock mass strength. Int J Rock Mech Min Sci 34(8):1165-1186. https://doi. org/10.1016/S1365-1609(97)80069-X

4. Tziallas GP, Saroglou H, Tsiambaos G (2013) Determination of mechanical properties of flysch using laboratory methods. Eng Geol 166:81-89. https://doi.org/10.1016/j.enggeo.2013.09.002

5. Pepe G, Piazza M, Cevasco A (2015) Geomechanical characterization of a highly heterogeneous flysch rock mass by means of the GSI method. Bull Eng Geol Environ 74(2):465-477. https:// doi.org/10.1007/s10064-014-0642-4
6. Sari M, Karpuz C, Ayday C (2010) Estimating rock mass properties using Monte Carlo simulation: Ankara andesites. Comput Geosci 36:959-969

7. Marinos P, Hoek E (2001) Estimating the geotechnical properties of heterogeneous rock masses such as Flysch. Bull Eng Geol Env 60:85-92. https://doi.org/10.1007/s100640000090

8. Langford JC, Diederichs MS (2015) Quantifying uncertainty in Hoek-Brown intact strength envelopes. Int J Rock Mech Min Sci 74:91-102

9. Hoek E. (2007). Practical rock engineering. http://www.rocsc ience.com/hoek/PracticalRockEngineering.

10. Edelbro C, Sjöberg J, Nordlund E (2007) A quantitative comparison of strength criteria for hard rock masses. Tunn Undergr Space Technol 22:57-68

11. Heidarzadeh S, Saeidi A, Rouleau A (2021) The damage-failure criteria for numerical stability analysis of underground excavations: a review. Tunnel Underground Space Technol 107:103633. https://doi.org/10.1016/j.tust.2020.103633

12. Abdellah W. (2013). Geotechnical risk assessment of mine haulage drifts during the life of a mine plan. PhD thesis, McGill University, Montreal, Canada.

13. Heidarzadeh S, Saeidi A, Rouleau A (2018) Assessing the effect of open stope geometry on rock mass brittle damage using a response surface methodology. Int J Rock Mech Min Sci 106:60-73

14. Heidarzadeh S, Saeidi A, Rouleau A (2019) Evaluation of the effect of geometrical parameters on stope probability of failure in the open stoping method using numerical modeling. Int J Min Sci Technol 29(3):399-408

15. Heidarzadeh S, Saeidi A, Rouleau A (2020) Use of probabilistic numerical modeling to evaluate the effect of geomechanical parameter variability on the probability of open-stope failure: a case Study of the Niobec Mine, Quebec (Canada). Rock Mech Rock Eng 53:1411-1431. https://doi.org/10.1007/ s00603-019-01985-4

16. Pathak S, Nilsen B (2004) Probabilistic rock slope stability analysis for Himalayan conditions. Bull Eng Geol Env 63(1):25-32

17. Park HJ, West TR, Woo I (2005) Probabilistic analysis of rock slope stability and random properties of discontinuity parameters, Interstate Highway 40, Western North Caroline, USA. Eng Geol 79:230-250

18. Hsu SC, Nelson PP (2006) Material spatial variability and slope stability for weak rock masses. J Geotech and Geoenv Eng 132(2):183-193

19. Jefferies M, Lorig L, Alvarez C (2008) 'Influence of rock-strength spatial variability on slope stability', Paper presented at the $1^{\text {st }}$ International FLAC/DEM Symposium, 25-27 August. Minneapolis, USA

20. Hoek E (1998) Reliability of Hoek-Brown estimates of rock mass properties and their impact on design. Int J Rock Mech Min Sci 35:63-68

21. Mollon G, Dias D, Soubra AH (2009) Probabilistic analysis of circular tunnels in homogeneous soil using response surface methodology. J Geotech Geoenviron 135(9):1314-1325

22. Cai M (2011) Rock mass characterization and rock property variability considerations for tunnel and cavern design. Rock Mech Rock Eng 44(4):379-399

23. Lü Q, Low BK (2011) Probabilistic analysis of underground rock excavations using response surface method and SORM. Comput Geotech 38:1008-1021

24. Chen G, Jia Z, Ke J (1997) Probabilistic analysis of underground excavation stability. Int J Rock Mech Min Sci 34:3-4

25. Pytel W, Świtoń J (2013) Assessment of the impact of geomechanical parameters variability on underground excavations stability using response surface method. Studia Geotechnica Mechanica. https://doi.org/10.2478/sgem-2013-0014 
26. Idris MA, Saiang D, Nordlund E (2011) Probabilistic analysis of open stope stability using numerical modelling. Int J Mining Min Eng 3(3):194-219

27. Griffiths DV, Fenton GA, Lemons CB (2002) Probabilistic analysis of underground pillar stability. Int J Num Analy Meth Geomech 26:775-791

28. Guarascio M, Oreste P (2012) Evaluation of the stability of underground rock pillars through a probabilistic approach. Am J Appl Sci 9(8):1273-1282

29. Zhao H, Li Z, Kong CS (2016) Probabilistic method to determine the overall rock block failure based on failure mode. Eng Trans 64(1):105-113

30. Kim K, Gao H (1995) Probabilistic approaches to estimating variation in the mechanical properties of rock masses. Int J Rock Mech Min Sci Geomech Abstr 32(2):111-120

31. Hoek E, Marinos P, Marinos V (2005) Characterization and engineering properties of tectonically undisturbed but lithologically varied sedimentary rock masses. Int J Rock Mech Min Sci 42:277-285

32. Grenon, M, Boudreau, C, Bruneau, G Caumartin, R. (2015). Statistical characterization of intact rock properties at a Canadian underground mining project. In Y Potvin (ed.), Proceedings of the International Seminar on Design Methods in Underground Mining, Australian Centre for Geomechanics, Perth, pp. 351-366.

33. Contreras LF, Brown ET, Ruest M (2018) Bayesian data analysis to quantify the uncertainty of intact rock strength. J Rock Mech Geotech Eng 10(1):11-31

34. Golder. (2012). Review of structural data analysis at Niobec Mine. Project 003-11-1221-0087 MTA Rev0, February.

35. Lajoie P.L. (2010). Caractérisation du massif de carbonatite de la mine Niobec sous le niveau 1000 et analyse de la stabilité du pilier de niveau. (Mémoire de maîtrise). Université du Québec à Chicoutimi, Chicoutimi, Canada. (In French).

36. Tremblay J, Bédard LP, Matton G (2017) Columbitization of fluorocalciopyrochlore by hydrothermalism at the Saint-Honoré alkaline complex, Québec (Canada): new insights on halite in carbonatites. Ore Geol Rev 91:695-707

37. Lavoie C. (2018). Analyse de l'effet du remblayage des chantiers souterrains de la mine Niobec sur leur stabilité. M.Sc. thesis, University of Quebec at Chicoutimi, Chicoutimi, Canada. (In French).

38. Bétournay MC, Gorsky B, Situm M (1986). Tetrauville limestone of the Niobec crown pillars comparison of strength and deformation properties from various tests. Division Report M\&ET/MRL 86-144 (TR), Mining Research Laboratories, CANMET, Energy, Mines and Resources Ottawa, Canada, Contrôle de terrains.
39. Labrie D. (1987). Étude de stabilité à la mine Niobec. Projet STM526, Centre de recherches minérales, supplément No. 4 : Essais en laboratoire. (In French).

40. Labrie D. (1997). Caractérisation et instrumentation du pilier horizontal situé entre les niveaux 600 et 700 de la zone 102 à la mine Niobec. Rapport LMSM 96-083 (RC), Laboratoires de recherche minière, CANMET, Énergie, Mines et Ressources Canada, Ottawa, Canada. (In French).

41. Desbiens $S$ (1997). Étude géomécanique du massif de carbonatite de la Mine Niobec au niveau 1000 et analyse de stabilité. (Projet de fin d'études). Université du Québec à Chicoutimi, Chicoutimi, Canada. (In French).

42. Corthésy R. (2000). Investigation géomécanique du 3e bloc minier : essais en laboratoire - Mine Niobec. Centre de développement technologique de l'École Polytechnique. Montréal, Canada. (In French).

43. Labrie D, Conlon B (2005). Essais de compression sur le matériau de la mine Niobec, Saint-Honoré (Saguenay), Québec - résultats finaux. Projet 603017.9 p. (In French).

44. Grenon M (2013) Essais de laboratoire - Résistance en compression uniaxiale - Résistance en tension indirecte. Université Laval, Québec, Canada, Laboratoire de mécanique des roches (LMR) ((In French))

45. Itasca (2014). Geomechanical Feasibility Analyses of Caving at Niobec Mine. Ref.13-2768-62, February.

46. Ganye J, Vasileiou A, Perras MA, Carter T G (2020) Influence of grain size and interlock on intact rock parameters. paper presented at the 54th U.S. Rock mechanics/geomechanics symposium, physical event cancelled, June 2020.

47. Langford JC (2013) Application of reliability methods to the design of underground structures. Ph.D. Thesis, Queen's University, Canada. pp 512.

48. Sari M (2012). Stochastic estimation of the Hoek-Brown strength parameters using spreadsheet models, Eurock, Stockholm, Sweden.

49. Rocscience. (2017). RocData V.5.0. Toronto, Canada.

50. Hoek E, Carranza-Torres, C, Corkum B (2002). Hoek-Brown failure criterion - 2002 edition. Proceedings of NARMS-TAC; Toronto $2002,1,267-273$

Publisher's Note Springer Nature remains neutral with regard to jurisdictional claims in published maps and institutional affiliations. 